(Journal of Literary Criticism)

ISSN: 2602-46i6

Cilt III, Sayı I, Mart 2019

YÜKLENME TARİHI: 09.II.20I8 KABUL TARİHI: I9.I2.20I8 YAYIN TARIHI: 27.03.20I8

Künye: Duman, Mehmet Akif (2019). “Monroe C. Beardsley'in Absürtlük Teorisi'nin Oğuz Atay'ın “Unutulan” İsimli Hikâyesinden Misaller İle İzahı", Edebî Eleștiri Dergisi, c. 3/1, s. 74-105.

DOI: $10.31465 /$ eeder.481086

\section{Dr. Öğr. Görevlisi Mehmet Akif DUMAN}

Turcology at the Department of Slavic, Turkic and Circum-Baltic Studies of Johannes Gutenberg University Mainz-

Germany

mehmetakifduman@outlook.de

ORCID: 0000-0002-5633-8268
MONROE C. BEARDSLEY'İN

ABSÜRTLÜK TEORİSI'NİN

OĞUZ ATAY'IN “UNUTULAN"

İSİMLİ HİKÂYESİNDEN

MİSALLER İLE İZAHI

EXPLANATION OF THE

THEORY OF ABSURDITY BY

MONROE C. BEARDSLEY WITH

EXAMPLES FROM THE STORY

"THE FORGOTTEN" BY OĞUZ

ATAY

\section{ÖZ}

Metaforun "Absürtlük Teorisi" kapsamında bir hikâyeyi değerlendirmek, bilhassa metnin gerçeklik karşısında sorgulanmasını ve gerçeklik karşısında edindiği konumun kendi içinde oluşturduğu düzen çerçevesinde değerlendirilmesini gerekli kılar. Bir kelimenin toplum içi bir uzlaşmayla -o toplumun bütün fertleri için- tek bir anlama gelecek ve bu anlamın tamamını gösterecek şekilde bir manaya delâlet etmesi (lafzın vaz'î delâleti) ile başlayan metaforik süreç "mantıksal zıtlık" ve "kendi içinde çelişenlik" ile devam eder. Metaforun tanımı, uygunluk, tesadüfilik ve zaman gibi mevzular absürtlük için hemen daima bir muhalefet tavrı içinde yürür. Absürtlük teorisi bu bakımdan hakikat ve hakikat algisı ile sürekli bir hesaplaşma içindedir. Dolayısı ile "rüyâ" ve "hayal" içerikli hikâyeler bu teorinin izahı için oldukça müsaittir. Oğuz Atay'ın "Unutulan" isimli hikâyesinde de her iki katman kendi içlerinde oluşturdukları süreklilik ile üst üste konuşlandırılmıştır. Gerçekliğin bükülmesi, kırılmas1, düğümlenmesi ve yeniden biçimlendirilmesi arasındaki farkları da vurgulayarak "absürtlük" kavramını teorik olarak izaha çalışmak ile mühim bir kavramsal kargaşaya da temas etmiş olacağız.

Anahtar Kelimeler: Monroe C. Beardsley, Oğuz Atay, absürtlük, metafor

\section{ABSTRACT}

Evaluating a story within the framework of the "absurdity theory" of metaphor requires questioning the text in comparison to reality and evaluating the position it has taken within the framework of its own system versus reality. The metaphorical process which begins with a socially consensus on the meaning of a word - a word means the same for all individuals of a society continues with "logical contrast" and "inner contradiction". Subjects like the definition of metaphor, compatibility, randomness and time are always causing a opposition inside of absurdity. The theory of absurdity in this regard is in a conflict with reality and perception of reality. Thus, stories that include "dream" and "imagination" are very appropriate for explaining this theory. In the story "The Forgotten" by Oğuz Atay, both levels were positioned one above the other, along with the continuity they create within. In emphasizing the differences between bending, breaking, knotting, and reshaping reality, we would have mentioned an important conceptual chaos in explaining the concept of "absurdity."

Keywords: Monroe C. Beardsley, Oğuz Atay, absurdity, metaphor. 


\section{Giriş}

Metaforun absürtlük teorisini Oğuz Atay'ın Unutulan (1987) isimli hikâyesine tatbik etmeden evvel teorinin ana hatları ile izahı faydalı olacaktır. ${ }^{1}$ Beardsley metafor kavramını ele alırken özellikle metaforik atfın absürtlüğü üstüne yoğunlaşır. Aslında Beardsley için cins ismin çağrıșımı Black için olduğu kadar mühimdir (Duman 2018: LS 5.10, s.445 ve LS 4.5.6, s.367-8). Ay1ca Beardsley aracın (vehikel yani müşebbehün bih) başına bir değişiklik gelirse bunun metaforun etkileşim teorisine eklenemeyeceğini var sayar: "Aman Allahım! Eski sevgilisi yatıyordu yerde. Tozlanmış, örümcek bağlamış; tavan arasındaki her şey gibi. Kitap sandığına ve resim tahtalarına örümcek ağlarıyla tutturulmuş eski bir heykel gibi” $(\mathrm{s} .29)^{2}$

Parçada "eski sevgili" (müşebbeh) ile "heykel" (müşebbehün bih) arasında kurulan ilgide heykel üstünde yapılacak değişiklikler eski sevgiliye olduğu kadar vech-i şebehe karşı da sorumludur. Zira tarafeyn arasında kurulacak bağlantı için esas olan Beardsley nazarında daha ziyade benzetmenin hangi ilgi ile kurulduğudur.

Absürtlük teorisini her şeyden önce estetik içinde geliştirir Beardsley. Sonraki zamanlarda kaleme aldığı "Metaforik tornasyon/ bükülme"de (The Metaphorical Twist) "nesneye yaklaşım" ve "kelimeye yaklaşım" arasında ayrım yapar (Beardsley 1962/1983, 120). İlkini "nesne mukayesesinin metafor teorisi" ve diğerini de (ki favorisi budur) "kelime muhalefeti teorisi" olarak adlandırır (Beardsley 1962/1983, 121). Yani "Delikten yukarı doğru bir el feneri uzandı" (s.27) dendiğinde "delik" ve "fener" kelimeleri ile bunların nesnel karşılıkları arasında bir çatışma olacaktır. Burada kastedilen temel olarak "lafzın vaz'î delâleti" yani "mutâbakat"tır.

\section{Lafzın Vaz'î Delâleti}

Lafzın vaz'î delâleti bir kelimenin toplum içi bir uzlaşmayla -o toplumun bütün fertleri için- tek bir anlama gelecek ve bu anlamın tamamını gösterecek şekilde bir manaya delâlet etmesidir. Lafzın, kendi mevzûsu olan mânânın tamamına delâletidir. Masa, insan, kalem, ev, çiçek, ăgaç lafızlarıyla medlûlleri arasındaki mutabakat gibi. Burada aslında signifationun yani delâlet sürecinin temel unsurlarından signifikant'ın ( gösteren) sembolik tavrı vurgulanmaktadır. ${ }^{3}$

\footnotetext{
${ }^{1}$ Çalışmanın esas maksadı Beardsley'in absürtlük teorisini izah etmektir. "Unutulan” hikayesi sadece misaller ile sınırlı tutulmuş bilhassa kapsam ve hacim sorunu (yahut endișesi) sebebi ile yazar ve üslupla ilgili bir değerlendirmeye girmekten imtina edilmiştir.

${ }^{2}$ Tekrardan kaçınmak maksadı ile sadece sayfa numarası verilen alıntılar Oğuz Atay'ın "Unutulan" isimli hikâyesine aittir.

${ }^{3}$ de Saussure 2001,14; de Saussure $1982,28$.

Gösteren ve gösterilen arasındaki ilgi Saussure için soyut değildir tam anlamıyla; daha sert, ayrılmaz, etkilenmez, neredeyse mekanik bir ilişki vardır aralarında. Onun "keyfilik" tezinde aralarındaki ilişki daha gelişigüzel izah edilmiş olmasına rağmen rabıta sonraları "sıkı" tutulur. Buna "ağaç" kelimesi misal verilebilir. Bu kelime telaffuz edilir edilmez "akustik görüntü; sesli bir resim" özelliği öne çıkar. Bu ifade kişide İngilizcesi olan "tree"yi çağrıştırabilir. O zaman sigfikant, "tree" olur. Ya da ağaç resmi, yeşil dalları gövdeleri olan bir nesne de canlanabilir. O zaman gösterilen ağacın kendisi olur. İşte bu bireysel farklılık sebebi ile Saussure keyfi olarak niteler bağlantıyı. Akustik görüntü için kullanılan seslerin tasavvur ile fiziksel bütünlük içinde olması ise sonraki aşamadır (de Saussure 2001,76-79, de Saussure 1982 ,97-100; ayrica bkz. de Saussure [1916]/ 1995).

Mesela Derrida'ya göre konuşma (ve onu oluşturan sözcükler) şey/nesne ile onu koruyacak, refere edecek bir ilişkiye sahiptir; yani aslında masa, masa değildir de "masa" kelimesi masa'yı ifade eder;
} 
Nietzsche'nin gözünde "kavram", dış dünyanın üçüncü dereceden bir yeniden temsilidir ve sadece metaforun bir metaforudur. Sözcük ve kavram arasında bir özdeşlik yoktur. Bütün kavramların örnek olarak başvurabileceği bir aşkın kavram veya bir idea da bulunmamaktadır (Spivak 1976, s.XXII). Metafor hakkındaki ilk ciddi yargıya varmadan önce bu güçlü argümanı kullanır Nietzsche. Kastedilen "ağaç" eğer gerçekten "ağaç" ise ona başka dillerde "tree" yahut "Baum" yahut "arbore" yerine sadece "ağaç" denmesi gerekir. Farklı diller yan yana getirildiğinde göstermektedir ki kelime "hakikat"i göstermez; asla yeterli ifade kurgusu mümkün değildir. Öyle olsa idi zaten bu kadar çok dil olmazdı, der Nietzsche $(1999,879)$.

Şu hâlde buradaki mutabakat "o dili konuşanlar" ile sınırlıdır. Zikredilen adlandırmanın ne kadar kuvvetli ve idrak sapmasına zemin hazırlayıcı olduğunu aşikardır. Bunu birkaç kelimenin görsel karşılıklarını zikredip delâlet düzenini tetkik etmek ile görmek mümkündür:
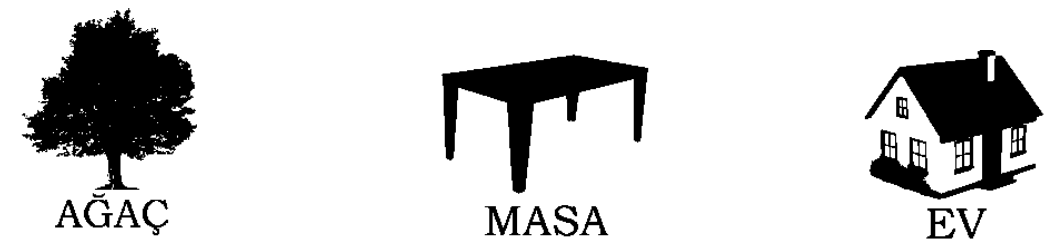

Ağaç denince akla neden servi gelmez yahut çınar, yahut çam, yahut söğüt? Mesela üzüm salkımı da bir ağaçtır, saksıya sığacak ufaklıktaki bonsai de. Masa denince de akla takriben yukarıdaki şekil gelir. Halbuki farklı ebat ve renklerde yüzlerce masa çeşidi vardır. Hatta dörtten fazla ayaklı, tahta olmayan veya dikdörtgen olmayan (kara, üçgen, daire, altıgen vb.) masaların olması da gayet tabiidir. Ev klişesi ise daha dar bir alanda görsel karşılık bulur. Oysa apartman, villa, hatta şato bile "ev" üst başlığı altında yer bulabilir. Nihayetinde ev "içinde yaşanılan yer"dir. Ayrıca evin çatısı düz de olabilir, pencereleri dikdörtgen olmak zorunda da değildir.

Lafzın vaz'î delâleti bilhassa üç bakımdan ele alınmalıdır.

(1) Klişe. Eğer "kaplan" kelimesini edinmek istiyorsak onun çizgili olması gerekliliğini de almış oluruz. Yani "kaplan” klişesi “çizgili"dir (Putnam 1975/1996, 30 vd; Zemach 1976, 116-127). Bu tavır en çok klişenin oluşturduğu (geçici ama sağlam) zemine ihtiyaç duyan çocuklarda görülür (bkz. Duman 2018: LS 4.5.4, 3635; LS 7.3, 487-94 ve LT 1.2; 9. 10. ve 11. Alanlar)

(2) Ölü sevgili tasvirine devam edilir: "Sağ kolu bir masanın kenarına dayalı; parmakları kalem tutar gibi aşağı kıvrılmış, boşlukta" (s.29). Masa kelimesi ortak alandaki kelimeler ile ilişkinin bir sonucudur. Sandalye, koltuk, oturak, mobilya, kanepe, bank, tabure, vazo, örtü vb. kelimeler olmaz ise; yani kelime tek başına kısmen belirsizlik içinde kalırsa, analizi ve tanımı mümkün olmaz (Lyons 1991,16).

kelime masa'dan daha masa'dir (Derrida 1967/1974,473).

Signifikant 'ların arabuluculuk rolü görmezden gelinecek yahut unutulacak cinsten değildir. Signifikant öyle bir enstrümandır ki onun aracılığı ile kaybolan diğer bir signifikant ifade edilebilir. (Lacan 1997, 258). Yani "heykel" eski sevgili yerine geçmemiş, bizzat o olmuştur.

Dilsel ifadedeki bu farklı sistem düzeninin Jakobson'un "Dilin ikili doğası/ çifte karakteri" tasavvurunda nasıl işlediğini izah için bkz. Bormann 1993,51. 
(3) Sınırların çizilememesi ciddi anlamda belirsizliğe (Vagheit/ vagueness) sebep olur. Heykele benzetilen sevgilinin nasıl bir heykele benzetildiğinden emin olamayız. "Orada, tavan arasında olduğunu unuttum sonunda. (Onu unutmadım tabii.) Ne bileyim, daha mutsuz insanlar vardı; onlarla uğraştım" (s.31) diyen kadın insan diyerek neyi anlatır? Hangi cinsiyetteki, boydaki, kilodaki, ırktaki veya yaştaki insan, "insan"1 temsil eder? (bkz. Duman 2015).

\section{Ana Hatları ile Absürtlük Teorisi}

"Kelimeye yaklaşım", "söz+lü muhalefet" teorisi Beardsley için karakteristiktir; zira iki nesne arasındaki mukayese (nesne mukayesesi teorisinde kastedildiği gibi) hiç de mevcut görünmemektedir. ${ }^{4}$ Bunun yerine tabii niteleyici (modifikatör) bizzat iki anlam katmanına sahip ise metaforik biçimde dilin özel bir performans1 yahut bir kelime oyunu mevcuttur (cinas gibi). Mesela "Sokağa firlamak, 'ona' gitmek için, öldürücü bir ümitsizliğe düşmek istedim." (s.32) cümlesinde "öldürücü bir ümitsizlik" nesnel karş1lığa sahip değildir. Bu yüzden niteleyici üstüne odaklanırken buradaki kastın gerçek olmadığını (öldürücü ümit olmaz), mübalağa yapıldığını ve nihayetinde hakikat-edebi gerçeklik arasındaki rabıtanın hakikatin aleyhine olduğunu unutmamak gerekir.

Buradaki esas kasıt semiotik kapsamında da ele alınabilir. ${ }^{5}$ Kelime harflerden oluşan hali ile gösterdiği nesnenin sadece işaretidir. Ama buna rağmen "ağaç" kelimesinin diğer tüm ağaçlardan daha fazla ağaç olması kelimeyi bir anda hakikat karşısında "üst kavram" (archilexem) yapar. Yani "kedi" kelimesi yaşayan canlı kediden daha fazla kedi'dir.

"Ben tavan arasındayım sevgilim! diye bağırdı delikten aşağı doğru. Eski kitaplar bugünlerde çok para ediyor. Bir bakmak istiyorum onlara." (s.27). Sorun tam olarak şudur: Buradaki "para" kelimesi gerçek paradan bizi uzaklaştırdığı için gerçeklikle bir çatışma içine gireriz; bu kurgusal boşluk tam da yazarın absürt bir kurgu oluşturmasına vesile olur. Kelimenin diğer kullanımları şu şekilde olabilir: "bu işte çok para var", "parasız olmaz", "paran kadar konuş", "para pul dediğin nedir ki", "hele bir para kazanacak yaşa gel". Mecazi anlamda olsun olmasın kelimenin dört harfli sureti cüzdana giren kâğıt parçasından çok daha soyut, zayıf ve değersiz olmalıdır. Fakat bu yanılgı ziyadesi ile kuvvetli olduğu için para rakamlara, sayılara ve karta indirgendiğinde üstündeki denetim de o oranda "bireysellik" dışına çıkar. Yani kredi kartından para harcayan bir kişi gerçek para ile değil de "para" kelimesi ile yahut paranın simgesel karşılıkları ile muhatap olduğu için harcamaların ucunu kaçırabilir. Dolayısı ile "kelimeye yaklaşım" ile "nesneye yaklaşım" arasındaki

\footnotetext{
${ }^{4}$ Mevcut olup olmama çeliş̧kisi gerekliliğin üstünü örtmemektedir. Metaforun iki ya da daha çok "şey" arasındaki benzerliği vurgulaması veya bunları mukayese vasıtası olması Searle tarafından da tekrar edilir. Searle, Aristoteles'i bu teorinin temsilcisi sayar (1979/ 1982, 107 ve 115)

${ }^{5}$ Malumat için yakın tarihte yayınlanacak şu makalelerimize bakılabilir:

- Sabahattin Kudret Aksal'ın “Vav'lar”'ının Semiotik Bakımdan, John R. Searle'ün Divergence Bakışı İçinde ve Dil-Eylem Teorisi (Speech-Acts) Çerçevesinde Ele Alınması,

- Charles Sanders Peirce'in Semiotik Anlayışı'nın Bühler'in Organon Modeli İlavesi ve Memduh Şevket Esendal'ın "Mendil Altında" Hikayesinden Misaller ile Tahlili,

- Ömer Seyfettin'in "Yüksek Ökçeler" Hikâyesinin Pragmatik Tavrı Eşliğinde Semiotik Kavramlarından "Sembol" ve "Simge" Ayrımı ve "Göstergebilim" Yanlış Adlandırması Kapsamında Eco'nun Semiotik İdraki
} 
mesafeyi iyi ayarlamak absürtlük tavrında başarılı olmanın en temel kaidelerindendir.

Eğer yüklemsel unsur (yüklem vazifesindeki dil bütünü) metafor olarak "özne" ile bağlantılı ise yüklem kendi normal "anlam genișliğini”" kaybeder. Sebep yeni bir "anlam baskısı" içermesi; yani yeni bir anlam katmanına geçilmesidir. $\mathrm{Bu}$ da muhtemelen başka bir bağlantı içermeyecektir. Bu durumda "bükülme/twist" bir iç gerilimle olur. Yahut metaforun kendi iç karşıtlıkları ile vuku bulur (Beardsley 1962/1983, 121).

"Işı̆̆ın altından kaçmağa çabalayan bir hamam böceği takıldı gözüne, kendine geldi. El feneriyle izledi böceği: Çirkin yaratık, yukarı çıkmağa çalışıyordu ağlara takılarak. Böceğin ayakları, elbiseyi parçalar diye korktu. Y1llar geçmişti, küçük bir dokunuşa dayanamazdı, kim bilir?” (s.32-3)

Böceğin ayaklarının elbiseyi parçalamaktan korkulması yeni bir anlam katmanına geçirir bizi. Elbisenin yani kişinin hassaslığ 1 üzerine yapılan vurgu dolaylı olduğu için edebi bir tat alırız. Burada izah için seçilen böcek öznesinin parçalamak ile alakası mevzubahis bükülmeye uğramadığı için mantıksızlık yani absürtlük bize kabul edilebilir gelmektedir.

Bu hususu izah etmek gerekir; ama unutmamak lazım ki bu bakış Beardsley'in favorisi sayılabilir. Bu durumda kullanılan "yüklem" unsurunun kaybı söz konusudur. Zira yeni bir "anlam yükü; anlamsal kasit" elde edilmektedir. Yani artık yeni bir ifade işaret edilecek; normal anlamsal çevre artık aynı sınıfa karşılık gelmeyecektir. O halde "yüklem" unsuru yeni bir anlamsal maksada sahip olacağg için "konu/vaziyet" metaforik dönüş halini alacaktır.

$\mathrm{Bu}$ "dönüş" (twist) neden meydana gelir, sorusu mucibince "metaforun metaforlaşması" gibi bir çatışmaya geri döner Beardsley; zira bunun kelimesel ifadesi de yoktur (Beardsley 1962/1983, 127 vd). Bu çatışma metaforu oluşturan kelimelerin birbiri ile "zıtlık" oluşturmasında yatar. Mesela:

"Düzen içinde yaşamayı bir bakıma sevdiğim halde, dayanılmaz bir pislik ve pasaklılık içinde çırpındım." (s.32)

"Yıllardır bu tozlu, örümcekli karanlığa çıkmamıştı. Işı̆ğ gören bazı böcekler kaçıştılar. Korktu; fakat, yararlı olacağını düşünmek kuvvetlendirdi onu" (s.28)

Düzen ve pasaklılık, pislik arasındaki bir zıtlık var. Aynı şekilde karanlık ve 1şık arasında da. Kastedilen böylesi bir zıtlık değildir. Kastedilen aslında yan yana bulunamayacak ögeleri (ki bu da zıtlığa az da olsa derinlik kazandırır) bir arada ama mantıksal reddediş olmadan kullanmaktır.

"Aman Allahım! Eski sevgilisi yatıyordu yerde. Tozlanmış, örümcek bağlamış; tavan arasındaki her şey gibi. Kitap sandığına ve resim tahtalarına örümcek ağlarıyla tutturulmuş eski bir heykel gibi. Sağ kolu bir masanın kenarına dayalı; parmakları kalem tutar gibi aşağı kıvrılmış, boşlukta" (s.29)

Teşbih, tavan arasında bulunan eski sevgili ile "gibi" ilişkisi içine giren ifadelerin normal şartlarda yan yana getirilmesinin imkansızlığı ölçüsünde güç kazanır. Mesela bu hâli ile öylece oturan eski koca (hayali) heykele benzetilmektedir. 
Bu ve benzeri bir durumda teşbihin neden yapıldığ 1 yani vech-i şebehin zikredilmesi yahut en azından sezdirilmesi gerekir. Bu durumda öylece duran, örümcek ağ 1 bağlamış birinin heykele teşbihi pek de kuvvetli bir sanatsal misal olmasa gerektir. O halde ifade gücünü nereden almaktadır? Çerçeve biraz genişletildiğinde şu soru akla gelebilir: "Bir evin tavan arasında eski kocanın ne işi olabilir?" Normal bir hayat süren karı kocanın tavan arası ile eski kocanın kafasından vurulmuş hayali bir araya geldiği vakit mantıksızlık başlar. Bu da absürdün temelidir. Bir ifadenin metafor ile arasında hasıl olan bu zıtlık anlamsal yapının bizzat içinde mevcuttur (Beardsley 1962/1983, 129). Bu mantıklı bir zitlıktır. Tabii niteleyici (modifikatör) kendi metaforik dönüşünü/bükülmesini verir burada. Biraz da bu "mantıklı zitlık" üzerinde durmak faydalı olacaktır.

\section{Mantıklı Zitlık}

Beardsley'e göre "mantıklı zıtlık" hem doğrudan uyumsuzluk belirtilen özellikleri hem de çeşitli kelime varsayımları arasındaki dolaylı uyumsuzlukları kapsar. Farklı varsayımların farklı hatalı yapıları (bariz yalanları da diyebiliriz) oyuna sokması kaçınılmaz olur. Dolaylı uyumsuzluk belirten özellikler de mesela “cümle metaforu” biçiminde işaret edilebilir (Beardsley 1962/1983, 129). Yüklem unsurunun yeni bir anlamsal kasıt kazanması da "nasıl" sorusunu peşinden sürükler. Black'in düşündüğü gibi, yükleme ait görünen her yan anlam onun çağrışım alanına dahildir. Yani "bu nasıl mümkündür" sorusunun cevabı "ifadenin çağrışım ile yer değiştirmesi bunu mümkün kılar” olacaktır (Beardsley 1962/1983, 130).

"Sonra hatırladı: Bir gün tavan arasına çıkmıştı eski sevgilisi, şiddetli bir kavgadan sonra. İkisinin de, artık dayanamıyorum, dediği bir gün. Ayrıntıları bulmağa çalıştı: Belki de büyük bir tartışma olmamıştı. Biraz kavgalıydılar galiba. Gülümsedi: Bu 'biraz' sözüne ne kadar kızardı. Onu tavan arasında bırakıp sokağa firlamıştı: Öleceğini hissediyordu” (s.30).

Yan anlamın çağrışım alanına dahiliyeti de yine "bağlam" içinde ifadenin genişlemesi ile mümkündür. Yani yukarıdaki parçanın son cümlesinde "öleceğini hissetmek" ifadesi ancak diğer ifadeler, cümleler idrak edildiğinde sabit bir anlam kazanır. Şayet bir kelime diğeri ile bu şekilde hemhâl edilecekse ana anlam ile diğer kelimeler arasında mantıksal bir zıtlık oluşacaktır. Burada (tabii olarak) ana anlamdan yan anlama bir kayma olur. Ki bu da metaforik olarak anlaşılması gereken kelimeye yöneliktir. Bu anlaşılabilir bir şeydir; absürt değildir Beardsley’e göre (Beardsley 1962/1983, 129).

Mantıksal idrak sürecinde absürtlügün bu şekilde temel element haline getirilmesi teorinin sorgulanmasını da beraberinde getirir. Beardsley yanılmış mıdır, sorusuna "hayır" cevabının verilebilecek olmasının sebebi konunun "Logical Absurdity" başlı̆ğ altında (Bearsley'in estetik farklılıkları üzerine dördüncü teorisi) zikredilmesi değildir. "Mantıksal absürt ifade" kesinlikle nefret uyandıracak (yahut garip karşılanacak) cinsten değildir; ama kolay kabul de görmez. Bu alg1 sürecinde reddedilmez (asla görmezden gelinemez) bilakis bir "ikincil" arayışında ikinci katmana yerleşmiş bir anlam suretinde fırsat doğurur (hatta yaratır) (Beardsley 1958, 138).

Beardsley bu "atfetme"yi farklı türlere ayırır. Bununla en az iki kelimeden oluşan dilsel ifadeyi anlar. Bunlardan ilki konuşma nesnelerinin sınıfını temsil/ifade 
eder. Bu biri diğerine nitelik atfettiği (yahut onu tadil ettiği) sürece belli bir tarzda biçimlendirilmiştir (yani karakterize edilmiştir). Bu değiştirilmiş olanı, tadil edilmiş olan ifadeyi Beardsley atfın "öznesi" olarak nitelendirir. Diğer ifade ise “niteleyici/değiştirici”dir (Beardsley 1958, 138).

"Kendi kendini muhtevi" ve "kendi ile çelişen" olmak üzere ikiye ayırır Beardsley "mantıksal olarak boş olan atıflar"1. Bu kendi kendini içereni "gereksiz ifade" biçiminde çevirmek mümkündür. "İki ayaklı iki ayağı olanlar" yahut da totolojiler; mesela "Insan insandır" buna misal verilebilir. Metaforik atıflar bu "gereksiz ifadeler"e değil de "kendi ile çelişen atıflar" sınıfina dahil edilir. Bunu dildeki her kelimeyi hakiki manasında algılayıp sorgulamak ile test edebiliriz.

"Oysa biliyordu: Aramızda, hiçbir yeni varlığın önemi yoktu; konuşmuştuk bütün bunları. Ben de onun inmesini beklemiş olmalıyım. Beni üzmek için inmediğini düşündüm önceleri. Sonra... bir türlü olmadı işte... çıkamadım: Gelenler, gidenler, geçim sıkıntısı, yemek, bulaşık, evin temizliği, 'onun' bakımı (çocuk gibiydi, kendisine bakmasını bilmiyordu), babamla annemin ölümü, bir şeyler yapma telâşı, önümde hep yapılması gereken işlerin yığılması" (s.31).

Modern insanın içine düştüğü bataklı̆̆ gayet kuvvetli bir şekilde özetleyen paragrafta bir erkeğin çocuk gibi bakıma muhtaç olması mecâzsız olarak algılanırsa dehşet verici bir şeydir. Bu ifade mantıksızdır. Bu ifade süregelen mantıksal süreç ile çelişirir. Kendi yemeğini yiyemeyen, kıyafetlerini değiştiremeyen, kişisel bakımı için başkalarına muhtaç bir çocuk olması bir erkeğin tam anlamı ile bir kabustur. $\mathrm{O}$ halde ifadenin -ki şu hâlde tüm anlamı olumsuz etkiliyor- başka bir katmana taşınması gerekir. Yani "Çocuk gibi kendisine bakmayı bilmeyen erkek" ile kastedilenin çelişki, gerilim ve mantıksızlık içermesi ifadenin metaforik katmanda değerlendirilmesini gerekli kılar.

Metaforun kendi ile çelişen atıflarda tadil edici özellik bakımından uyumsuzluk gösterir. Burada kastedilen özneyi işaret eden özelliktir. Ama tadil edici belli bir özelliği kastederse, özellik özne ile atfedilebilir. Okuyucu bu durumda kendi çelişkisi ile karşılaşır ve yapı dolaylı olarak oluşur (Beardsley 1958, 140). Prensip olarak, yazar çelişkinin kendi içinde olduğunu bilir; ama zaten mantıklı bir çerçevede yapılanmadan bahsetmez (bunu vadetmez). Eğer bundan bahsederse o zaman ciddi bir mantıksızlık/ çelişki hasıl olur.

"Onun bakımıyla ilgilenmedim, elbiselerini hiç gözden geçirmedim; belki de dikmediğim bir sökükten yemeğe başladılar hamam böcekleri onu. Deliği büyüttüler sonunda. Eliyle elbisenin altını yokladı. Neyse, iç çamaşırlarından öteye geçememişler. Derisi, olduğu gibi duruyor. Teni çok sicak sayılmaz ama, kalbi yerindedir herhalde" (s.31-32).

Yazar hamam böceklerinin eski kocayı yemesi ile mantıksızlık sürecinin ne kadar ileri gidebileceğini işaret etmiş olur. Yukarıdaki misaldeki gibi bu devam da ettirilir, absürtlük artar, zihinsel çelişkiler güçlendirilir; ya da devamı, tamamlama okura bırakılarak anlatım sürdürülür. Bunun cümle ve paragraf düzeyinde değerlendirilmesi mümkün ve mantıklı iken metnin tamamına yayılacağı da gözden kaçırılmamalıdır. 


\section{Kendi ile Çelişen "Unutulan"}

Hikâyede eski kitapları satmak amacı ile tavan arasına çıkan bir kadının eski kocası ile ilgili "şeyler"e rastlaması ve kısmî pişmanlıkları anlatılır. Eski kocanın bir ceset suretinde tasviri son paragrafa kadar sürer.

Belki de hamam böceği son parçayı taşıyordu. Kendini tutamadı: "Seni çok mu yalnız bıraktılar sevgilim?" dedi. Aşağıdan, başka bir deliğin içinden sevgilisinin sesini duydu:

"Bir şey mi söyledin canım?"

Elini telâşla kitap sandığına soktu, "Hiç," diye karşılık verdi aceleyle.

"Kendi kendime konuşuyordum." (s.33)

Kendi kendi ile konuşmak, hayal kurmak, düşünmek şeklinde bizim ciddiyetle takip ettiğimiz "eski kocanın cesedi" tasavvuru sonlandırılır. Ya okur en başından beri bunun sembolik bir kurgu içinde olduğunu biliyorsa? Bu durumda şu soruya odaklanmak absürtlüğün ne derece işlevsel bir enstrüman olduğunu gösterir.

A) Anlatılanları ciddiye almaz isek, yani en başından beri ölü kocanın simgesel bir anlam taşıdığını biliyorsak metin bir lezzet vermez. $\mathrm{O}$ vakit metnin okunması bile manasızdır. Bu ancak cevabı bilinen bir bilmeceyi dinlemek kadar zevk vericidir.

B) Eski kocanın gerçekten orada olduğunu sanıp ne olup bittiğine anlam vermeye çalışarak okuruz metni ve en sonunda simgesel kullanımı idrak ederiz.

C) Sembolik kullanımın farkında da olsak, bilerek bunu görmezden gelir; eserden edebî tat alır ve sonuç kısmındaki izah ile eksikleri tamamlarız. Bu da okurun kendini kandırması demektir.

Bunlardan en işlevsel olan tavır modern insan için sonuncudur. Kurt adamlar, vampirler, devler, uçan atlar, ejderhalar vb. ile ilgili ve hatta Süperman, Batman, Ironman, Thor, Hulk gibi hayal mahsullerinin baş rolünde olduğu filmler büyük bir heyecanla izlenir. Seyirci kendini kandırmak ve bir anlığına "yalan"1 veya "sahte"yi gerçeklik kabul etmekle mutlu olur; kısmî kopuş ile gerçeğin $2+2=4$ ederliğinden uzaklaşan zihin hafifler. "Unutulan" hikâyesinde tavanda ölü bir koca cesedinin olmamasına rağmen "var+mış gibi" yapılması ile kurgulanan boyut biz içine girdiğimiz müddetçe metaforiktir.

Metaforik atfın cümlede ön planda olduğunu bilinmektedir. Eğer atıf "dolaylı kendi ile çelişen" ise bu onu tezattan (oxymoron/ ỏ $\xi u \omega \omega \rho$ o) farklı kılar. Fiziksel olarak ölmediği, ruhunu teslim etmediği halde "ölüyorum" demek buna misaldir. Yani bu doğrudan kendi ile çelişim değildir. Ayrıca özne, tadil edici "çağrışım" sahibi ise atfa tabi olabilir (Beardsley 1958, 141). Metaforik atıf iki gerekli kısımdan oluşur:

(1) İki anlam katmanı arasındaki semantik fark.

"Babasının yüzünde gururlu bir somurtkanlık vardı. Aynı duvara asamam onları. Evin düzenini hızla gözünün önünden geçirdi. Yan yana olmak istemezlerdi; mezarda bile" (s.28). Evli bir çiftin mezarda dahi yan yana olmak istememesi sadece semantik katmanda çözümlenmeye müsaittir. Hakiki anlam ile (kişilerin birbirinden 
o kadar nefret etmesi) ve yan yana kazılmış mezarlarda yatmak (mezarlık tertibi) arasında böylesi bir fark vardır.

(2) Mantıksal bir katmanda mantıksal zıtlık (Beardsley 1962/1983, 130).

Aynı şekilde iki kişinin yan yana mezarlıklarda yatmayı istememesi, bunu talep etmeleri mantıksızdır. Ancak bu abartı idrak sürecini tamamlamaya yardımcı olduğu için (o kadar hazzetmemektedirler birbirlerinden) kabul edilebilir bir mantıksal tezat hasıl eder. İnsanın çeşitli özelliklerinin öne çıkması münasebeti ile hayvana teşbih edilmesi esnasında bu "mantıksal zıtlık" daha bariz bir hal alır: "Ali aslandır, tilkidir, kurttur, çakaldır, ayıdır vs." $\mathrm{Bu}$ teşbihler saf mantıksızlık olmalarına rağmen (bir insan nasıl bir hayvan ile eş tutulur) kabul edilebilir, algılanabilir ve ifadeyi kuvvetlendirir olmalarının sebebi zıtlığın mantıklı olmasıdır. Bu durumda "insan" müşebbeh ve "kurt" (diğer hayvanlara atfen) müșebbehün bih tek tek şüphe celp eder. Bu noktada Kubczak'ın önerisi mantıklıdır. İnsan ve kurt arasındaki rabıtanın tüm denotatum'u yani bütün çok anlamlı ifade yelpazesi ve özelde de dil-dış1 gerçeklik durumu olgusaldır (Kubczak 1978, 50).

Beardsley metafor kavramını "dolaylı kendi ile çelişen atıf" alanına sıkıştırmaz. "Bariz uydurma ifadeler"i de kapsar ki bunlar "kendi ile çelişen" değildir de bilakis saf absürtlüktürler (Beardsley 1958, 142). Dolaylı kendi ile çelişen atıflar (yani atfedilen özellikler) "cümlesel atıf" kapsamındadır; buna ilaveten "partikel" kullanım da sayılır (Beardsley 1958, 139 ve 142). İkincisi herhangi bir kısıtlamaya tâbî değildir. Bizzat böyle bir "partikel atıf"ın kendisi (mesela "melankolik sardunya" veya "beyhude kalem") fazlaca cesur olarak nitelenemez. Bununla ilgili ilginç bir tespitte bulunur Beardsley. İngilizce'de tüm sıfatları bir şapkanın içine, tüm isimleri de bir diğerinin içine koyup rastgele örnekler çekilse; tuhaf kombinasyonların mümkün (olası) anlamları yansıttığı görülecektir. İşte bu yaşayan bir dilin temel prensibidir ona göre (Beardsley 1958, 143). Bu nedenle aslında metafor olarak algılanacak ve yorumlanacak "atıf" (atfedilen özellik) yoktur da denebilir. Çünkü ciddi anlamda çok alternatifin bir araya gelmesi ve zihnin anlam tavrını zorlayıp metaforumsulaşması mümkündür. $\mathrm{Bu}$ durumda yazarın büyük bir avantajı vardır: okurun anlam vermek için elinden geleni yapma tavrı. Hikâyenin kahramanı ölü koca ile konuşsa, duvardaki bir delikten içeri kaynanası düşse, yahut (mesela) ölü doğan bebeği iskelet suretinde tavanda gezinse yine de yadırgamayız. Bunun sonucunda "mantıklı" bir izah beklentisi ile teskin oluruz. Oysa Atay'ın yaptığı gibi sis bulutu bir anda "Kendi kendime konuşuyordum" (s.33) savunması ile dahi dağ 1 tılabilir.

\section{Metafor nedir?}

Beardsley makalesine metaforun önemini işaret ederek başlar. "Metafor nedir?" sorunun cevabı ona göre bilhassa edebiyat bilimi ve felsefî estetiği ilgilendirmektedir. Dilsel bir fenomen olarak metaforun uygun/makul tanımı onun poetik fenomen suretinde analiz edilmesi ile desteklenecektir. Dolayısı ile Beardsley "metaforik ifadenin kendine özgülüğü̈" üstüne yoğunlaşır. Metaforik anlamın hakiki anlamdan ayrılması ve tanınması, teşhisi ve anlamı gibi hususlar da izah edilmesi gereken yönlerdir.

$\mathrm{Bu}$ konunun tartışmalı kısımlarını vermek hiç şüphesiz kolay değildir. Antik kaynaklı tanımları dahi farklı farklıdır metaforun. Bunların bir kısmı ki bilhassa 
Aristoteles, Cicero ve Quintilian ${ }^{6}$ kaynaklı olanlar, bir yazardan diğerine aktarılmış ve "tanınır, köklü" hale gelmiştir. Dolayısı ile Beardsley bilhassa modern zamanlardaki geniş tanımları da kasıtla büyük bir çoğunluğun genel anlamda eş değer olduğunu düşünür. Fakat aralarında önemli bir noktada fark da vardır. Beardsley'in maksadı ise (az evvel belirttiğimiz gibi) daha ziyade nesneye yaklaşım ve kelimeye yaklaşım arasında metafor analizi yapmaktır. Bu tasavvura göre kabaca söylemek gerekirse metafordaki değiştirici -mesela "kindar" (Spitefull) kelimesi "the spitaful sun"da eğer metafor ise- normal ifade fonksiyonundadır. Bu sebeple aynı anda bu cümlede ifade (bağlam içinde) aynı zamanda metaforik-olmayan'ı da ifade eder. Dolayısı ile metafor üstü kapalı mukayese'dir. Yani bir "eliptik benzetme" (smile) addedilen metafor temelde güneşin "kindar bir insan"a benzetilmesi ile hasıl olur. $\mathrm{Bu}$ bağlamda hem kindar insan, hem de güneş gösterilmektedir; yani burada iki nesne vardır (Beardsley 1962/1996, 120).

"Yalnız, ağların arasından elimi, onun kalbine götürdüğüm yer biraz karanlık. Rüya gibi bir resim" (s.32) cümlelerinde resim (müşebbeh) rüya ile (müşebbehün bih) alakalandırılmaktadır. Yani bu cümledeki teşbih müşebbehün bih olmayan "rüya"y1 da etkilemektedir. Yani "Unutulan hikâyesindeki rüyâ" ile "Unutulan hikâyesi dışındaki rüyâ" ister istemez mukayeseye girmektedir.

Akabinde Johnson'a atıfla devam eder Beardsley; "bir yerine iki tasavvur" üstünde durur. John Crowe Ransom metaforu "ithalatçı" (importeur) olarak niteler (Wordsworth 1950, 498-519); yabanc1 ögeler" "durum"a idhal edilmektedir. Yani bir nevi ülke dışındaki bir mal ülkeye taşınmaktadır. Bu "import" ifadesini alaya alır Beardsley. Ransom'un muhtemelen yer elması ve şekerlenmiş arı gibi egzotik lezzetleri düşünmüş olduğunu söyler. Metafor yabancı ve beklenmedik bir nesnenin bağlamdaki konumunu gösterir ve mantıksal fazlalığın (absürtlüğün) metne adapte olmasını, katkıda bulunmasını sağlar. Beardsley'in "local texture of irrelevance" dediği bu "ilave"yi Ransom şiirin temel sureti olarak görür. Teoriyi evvela "Objectcomparison Theory" olarak adlandırır Beardsley. "Nesne karşılaştırma teorisi"nin muhalifi olarak da "Verbal-opposition Theory"yi koyar; yani "kelime/söz+lümuhalefet"i. Bu muhalif teoride böylesi bir "import veya mukayese" kesinlikle yoktur; (modifikatörün bizzatihi iki anlam katmanına sahip olmasının yanında) bunun yerine dilin özel bir gücü veya kelime oyunları mevcuttur. Odaklanılması gereken yine kelime düzeyinde kelime ile bunların nesnel karşılıkları arasındaki çatışmadır.

"Resim çok tozlanmıştı. Tozlu da olsa tanıyor insan kendini. Parmağını 1slattı diliyle; tozlar önce çamur oldu, sonra... İlk kocasının gülümseyen yüzünü gördü parmağının ucunda. Aman yarabbi! bir zamanlar evliydim ben de... sonra gene evliydim. İnsan bir günde varamıyor bir yere, ne yapalım? Nereye? Tanımlayamadığım, bir ad veremediğim duygular yüzünden ne kadar üzülmüştük.” (s.28)

Anıları içinde boğulan kadının evliliği nitelemek için kullandığ "bir yere bir günde varılamaması" nesnel anlamda ve mantıksal düzeyse kelimeler için değerlendirilirse ilki "belirsiz", diğeri ise "çelişkili" bir yapı ortaya koyar. Evliliğin içini dolduran onlarca detayın bir kenara bırakılıp "bir yere varmak" olması onun

${ }^{6}$ Duman 2018: LP 1.3.3, ss.76-84; LP 1.4.3 (Aristoteles), ss.96-110 (Cicero); LP 1.5.1, ss.111-4 (Quintilianus). 
sadece neticesi olabilecekken iki evliliğin birden bu şekilde nitelenmesi "tam olarak ne denmek isteniyor" şüphesi ile okuru karşı karşıya bırakır. Okur "muhtemelen mutlu olamamak" karşılığını bulsa da yazarın başka bir şey kastetmesi, ortaya koyması ve desteklemesi gayet mümkündür. Nitekim ikinci koca ile ilişkileri (bilhassa son kısımdaki diyaloğun da gösterdiği üzere) gayet sorunsuz görünmektedir. Çelişki de tam bu noktada "hakiki anlam" esas alındığında hasıl olur. Eski kocasını bu kadar seven, ona bu kadar bağlı, bu kadar kaygılı bir kadın nasıl olur da bu kadar telaşlı olur ve sonunda nasıl tekrar umursamaz olur? O halde metaforik düzey için gereken (bilhassa mevzubahis usta bir yazarın eseri ise) doğrudan pragmatik katmanda düşünmektir. ${ }^{7}$ Metni dışardaki hayatın mantığı ile değil, kendi vadettiği, önerdiği ve ip uçları ile taktim ettiği dünya içinde değerlendirmek gerekir.

$\mathrm{Bu}$ teorik ayrımı biraz daha detaylandırmakta fayda vardır:

Beardsley "Nesne-Mukayese Teorisi”ni hem genel içinde hem de özel formda neden reddettiğini izah eder. Ardından potansiyel itirazları da göz önüne alarak "Sözlü- Muhalefet Teorisi"ni etraflıca izah edecektir.

Aslında Beardsley'in bir diğer tereddüdü de ancak bir noktaya kadar üstünde mutabık kalınan metaforun nesnel-katman'da m1 yoksa semantik-katman'da m1 değerlendirileceğidir (Beardsley 1962/1996, 121-2). Mesela "briar" kelimesi (Dornbusch: dikenli çalı veya diken) metaforik olarak ancak belli bir bağlam (kontext) içinde işlenebilir: "Ve alevin gül olduğu, dikenin duman/ deprem soğuk

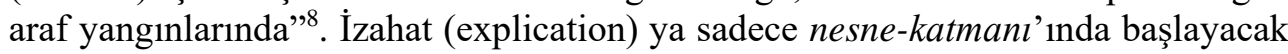

${ }^{7}$ (a) Sentaktik boyut, işaretlerin formel oluşumu ve birbirleri ile ilişkilerini düzenler. Eğer bir trafik işareti diğer grafik türlerinden yeterince ayrılabilir ve gerçekten tanınır ve anlaşılır ise o trafik işareti sentaktik bakımdan mükemmeldir. Bu aşamada tavan arası'nın metin dışındaki sembolik değeri (simgesel değil) ve metin içinde mesela başka bir obje ile mukayesesi sentaktik alana karşıllk gelebilir. (b) Semantik boyut ise işaretlerin nesneler ile olan ilişkisi ile ilgilidir. İfadelerin işaret düzeyindeki anlamında önemli olan alıcıya ulaşan mesajın bilgi kaynağından edinilen ile mümkün mertebe aynı olmasıdır. Trafik işaretine uyarlayacak olursak semantik açıdan mükemmel bir işaret ona bakanı yanlış yola sokmaz, durması gereken yeri gösterir; hülasa sürücü tarafından sorunsuz idrak edilir. Tavan arasının sembolik tavrından simgesele geçişi anlamalıyız buradan.

(c) Pragmatik boyut algılanan özne ve onun davranışların arasındaki ilişkiyi düzenler. Sentaktik olarak sorunsuz ve semantik olarak doğru anlaşılan trafik işareti trafik kuralları adına doğru olanın îfâsı olacaktır. Bu sembolik kullanımında ötesinde hikâyenin üslup özellikleri ile alakalı olarak sembolsimge geçişini ciddi anlamda etkiler (Hake 2002, 10).

Boyutlar arasındaki rabıta şu grafikte daha net görülür:

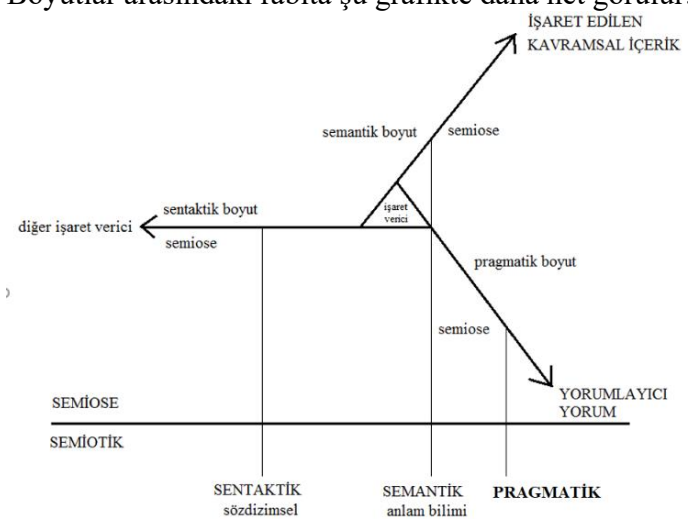

${ }^{8}$ [And quake in] frigid purgatorial fires/ Of which the flame is roses, and the smoke is briars. Eliot 
(ki bu durumda "diken"in karakteristik özelliklerinden bahsedebiliriz), ya da üstdilsel-katman'da (bu durumda da diken kelimesinin çağrışımlarını oyuna dahil ederek) ilerleyecektir. Dikenin yahut dikenli çalının genel özelliklerini ele alalım. İnsanı bir nevi tırmalayarak ilerlemesini engeller, batabilir; canını yakar. Belki rüzgâr esince hışırdar, gül ile bir bütündür vs. Hatta bu izahatı "gülü seven dikenine katlanır" sınırına kadar çekebiliriz. Ya da kelimenin çağrışımını devamen ilerlemeyi engeller surette "tırmalayıcı" ve işlenebilir olarak değerlendirebiliriz. Buna rağmen iki kısımdan birisi arasında tercih yapmaktan ziyade kesişme'yi (üst üste gelme) işaret eder Beardsley. Zira kelimenin çağrışımları kısmen nesnel yöne kaymaktadır. Yani çağnışım zannedildiği gibi sadece cismin hakiki özelliklerinin ötesinde (ya da üstünde) bir katmana bizi sevk etmez; bilakis kabul edildiği gibi bizatihi cismin kendisine de odaklanır. Yani "Ali aslandır" için sadece cesaret vasfinı cımbızlayıp aslanı geride bırakamayız. Tabi burada belirleyici olan daha ziyade "kabul"ün yanlış olup olmamasıdır. Bu Beardsley'in "nesne-mukayese teorisi”ne karşı ilk itirazıdır. Zira bu teorinin tutarlı takibi metaforun doğru olmayan ve yetersiz izahatını verecektir. Nerede "niteleyici" (modifikatör) çağrışıma sahipse (ki bu onun ilgili bağlamda kullanılması anlamına gelir) orada belirtilen nesnenin sıradan tesadüfi özelliği yoktur. Metafor istikameti "bilinçsizce" işaret etmez (ki dilin en üst düzey mecaz katmanından bahsediyoruz). Beardsley buradan hareketle şiire döner. Eliot'un mısralarında "briars" için önemli bir yan anlam gizlidir. Dolaylı olarak "dikenli taç” Hz. İsa'nın hayat hikayesine atıf içerir. Elbette sadece verilen mısralarla sınırlı kalınırsa "diken" için böylesi dinî bir anlam vermek mümkün olmayacaktır. Dolayısı ile Beardsley de bağlamın metaforik anlamın çözülmesi için bir basamak değil, bir gereklilik olduğunu teslim eder.

Teoriye ikinci itiraz mucibince bir nesne bulmak yahut tamamlamak metaforun öznesi ile mukayeseyi gerektirmektedir. Yani aslan, doğrudan "Ali"nin mukayeseye katılmasını gerekli k1lar. Richard'ın terminolojisinde "vehikel"in (müşebbehün bih) bulunması bu işleyişi sağlıyor idi (Duman 2018: LS 4.5, ss.35868). Kendine has imajlar, okur ve şiir arasındaki ciddi idrak bariyerinin tasviri olan kapıları ve bentleri her zaman geçersiz kılar (Beardsley 1962/1996, 122-3). Antonius Konuşması'ndaki (Random'un sözünü ettiği) mısralar Brutus'un kı1ıcı ile ilgilidir:

Bak, Caesar'in kanı onu nasıl da takip ediyor,

Daha fazlasını öğrenmek için, kapı önüne çöktügüüde

Acaba Brutus düşmanca mı çaldı hakikatte. (III 2, 178)

Ransom burada tenordan (kan) bir "page"e geçişten bahseder, ki "page" kapıyı açtı̆̆ına göre "vehikel" (müşebbehün bih) olmalıdır (Ransom 1947b, 436-56; 1947a, 640-658). Bu sirada muhtemelen uykusu bölünen bir kâhya veya derhal kavgaya müdahil olan bir çiftçi vardır. Tenor-Vehikel yani müşebbeh- müşebbehün bih (Duman 2018: LS 4.5.1, ss.359-61; LS 8.11.1, s.566-9) terminolojisi altta yatan metaforun bir mukayese olması zorunluluğu ile saptırıcıdır. Burada bir kendisine benzetilen bulunması (ki bu keşfedilir gibi de değildir) neticede bizim "page"e ulaşmamız ile karşılık bulur. Fakat Caesar'ın kanı ile ilgili olarak "rushing out of

1953,16

${ }^{9}$ Prensin hizmetindeki genç asilzade. Üniformalı hotel hizmetçilerine de denir. ABD ve Kanada'daki parlamento ve mahkemelerdeki genç asistanlara da bu ad verilir (Senatpagen). 
doors", "page rushing out of doors" ile aynı anlamda değildir. Bu göz önüne alınması gereken ilk anlamdır. Samuel Johnson'un karakteristik metaforu "Zaman, hayal gücünün en yaltakça bükülen tüm var oluş biçimleridir" ve William K. Wimsatt Jr.'ın buna istinaden işaret ettiğ i 'Zamanı kapıcı olarak tasavvur etmeye ihtiyacımız yok; ki o zaten efendisi olan fantezi önünde saygi ile eğilir" (Wimsatt 1941, 66) tasavvuru da bunu destekler niteliktedir.

\section{Uygunluk}

Beardsley'in "nesne-mukayese"ye yönelik üçüncü itirazı "uygunluk” ile ilgilidir (Beardsley 1962/1996, 123-4). Eğer bir metafor mukayese ise o vakit mukayesenin "uygun" mu "zorlama" mi olduğunu sormak icap eder. Burada Beardsley'in "benzetme"den ziyade "analoji" tavrına sahip ifadeleri hedef (yahut mercek altına) aldığını anlamak zor değil. "Sigara içtim durmadan. Evi, yaşanmaz bir duruma getirdim sonunda. Bir savaş sonu kargaşalığı sardı her yanı" (s.32) diyen kadın evin durumu (müşebbeh) ile savaş sonu kargaşası (müşebbehün bih) arasında bir mukayese yapmaktadır. "Ortalığın savaş alanına dönmesi” şüphesiz klişe bir kullanımdır ve C Tipi bir metafordur ${ }^{10}$, dolayısı ile uygun olsa bile etkisizdir. Zorlama ile kasıt daha başkadır:

Macbeth'te, kanlı bir hançerin uzun pantolon içindeki bacak ile mukayesesi (II 3) bu "uygunluk" bakımından değerlendirildiğinde Cleant Brooks ${ }^{11}$ (1906-1994) tarafından 19. yy eleştirilerinde yer alan Shakespeare "bizi başarısız mukayeseleri ile kendinden iğrendirmektedir" yorumuna mutabık düşer. Bu kelime ile kastedilen esas sorunu (/soruyu) daha da netleştirir Beardsley. Hançer'in hangi özelliği, metaforik özelliğin yan anlamı ile ilişkilendirilmiştir? Nasıl olmuştur da hançer, bacak ile mukayeseye girmiştir? Burada aslında teoriyi mühim yapan kırılma noktasına dikkat etmek gerekiyor. Klasik algıda mühim olan müşebbehtir ve müşebbehün bih ona yönelik, ona hizmet eder görünür. İzahı daha anlaşılır kılmak için misal verir Beardsley; "Benim aşkım, benim Schopenhauer'umdur." Mukayese

\footnotetext{
${ }^{10}$ Metaforları üçe ayırmak mümkündür: Tip-A: Masif Metaforlar: Poetik kıymetleri yüksektir. Okur yahut muhatap bunlardan edebî, estetik bir tat alır. Çabucak kavranmazlar. Kısa bir şekilde akla gelecek yakın anlamlıları yahut kolayca yerine konabilecek eş değerlileri yoktur. Metaforik arka plan hazır değildir; verilmemiş̧tir. Bunlar basit "mecâz"lar değildir; deyimsel değildirler, banal değildirler, klişe değildirler. Semantik bir değer taşırlar. Az ya da çok mübalağa ve benzerlik (teşbîh) taşırlar. Banallik yahut sıradanlık sınırına taşınmaları zaman ile alakalıdır; kullanıla kullanıla biçim, form ve tip değiștirmeleri normaldir. Esas ve ideal form budur. Bunlara "saf metafor" veya "aktif" metafor da denebilir. Tip-B: Zayıf Metaforlar: Şiirsel kıymetleri düşüktür. Okur yahut muhatap ya az miktarda edebî tat alır; yahut hiç almaz. Çabucak kavranırlar, yerlerine konacak kelime yahut ifadeler mevcuttur, ki bunları tasavvur uzun sürmez. Bunlar basit mecâzlardır, deyimsel olabilirler. Banal, sıradan, bayağı ve klişe olma eğilimindedirler. Mübalağa tesiri pek hissedilmez. Bunlara "sözde metafor", "sahte metafor" ve "uykudaki metaforlar" denebilir. Tip-C: Klişe veya Ölü Metaforlar: Hiçbir poetik değer taşımazlar. Okur yahut muhatap hiçbir şekilde metaforik tesiri hissetmez. Çok sık kullanılırlar, herkes tarafindan bilinirler; öyle ki küçük çocuklar tarafından bile kullanılabilirler. Deyimseldirler, kalıplaşmış ifadelerdir çoğu. Bu tipteki bir metaforu belirlemenin en kestirme yolu (deyim kalıbı dışında) kelimenin bağlamdan bağımsız olarak da atıfta bulunabilmesidir. Yani "aslan metaforu" dendiğinde "aslan" kelimesi bir cümle içinde kullanılmasına gerek olmadan zaten peşinen ve hiçbir hayal gücü, idrak, tasavvur kabiliyeti gerektirmeden "cesaret"i ifade ediyorsa o vakit kelime bu gruba girer. Bunlar banal, basit, sıradan, bayağı ve klişedirler. Mübalağa tesiri hissedilmez. Bunlara "ölü metafor", "donmuş metafor", "klişe metafor" veya "soyu tükenmiş metaforlar" da denir (Duman 2018: LT 1.3, ss.624-5). ${ }^{11}$ Shakespeare şârihlerinin bu metaforu nasıl rahatsız edici biçimde izah ettiklerini eğlenceli bir yolla göstermektedir. [çev. Paradoxie im Gedicht - Zur Struktur der Lyrik (Frankfurt 1965), s.51].
} 
teorisine göre sormamız lazım: Sevgili ile Schopenhauer'nun bir arada anılma sebebi nedir? Yani ortak noktaları nedir? Onun sevgilisini de tanımıyoruz ayrıca. Bu soruyu zikredenin kim olduğunu ve aradaki bağ ile ne kastedildiğini bilmeden (bağlama vakıf olmadan) cevaplamamız mümkün değildir. Daha makul olan soru ise şudur: Schopenhauer'nun hangi olası anlamları "sevgili"ye uyar ve hangi uyum ile bağlam çözümlenebilir (Beardsley 1962/1996, 124).

\section{Paul Henle'ye Bariz Muhalefet}

Makalenin ikinci kısmında Beardsley daha net bir hedef belirterek Paul Henle'yi karşısına alır. Aslında bu ifadeyi "sanırım" tedbîrî ifadesi ile taktim eder; yani nesne-mukayese için takınılan muhalif tavır aynı ölçüde Paul Henle'nin temsilcisi olduğu varyasyonu da kapsamaktadır; yani ikonik signifikasyon teorisini. ${ }^{12}$ Henle, Beardsley'in kanaatine göre isimlendirilen her iki teoriye de tâbî görünür. Gerçi onun teorisine göre "söz+lü muhalefet" "okur-kabul'üne göre tanımlanır, akabinde okurun "şaşırması" (şok/shock); "manaya muhalefet"e (anlamın çatışmasına: clash of meanings) sebep olur (Henle 1958, 182-3; 1969, 91-92). Fakat bu muhalefet yazara bir itiraz değil de garipseme, parçaların tam birleşmemesi ve idrak edememe şeklinde tezahür eder.

Beardsley buna mukabil teoriyi metaforun etkisi ile değil bilakis dilsel yaplst ile açıklamak ister. Ona göre Henle bu konuda fazla bir șey söylemez ve teorisi bașka teorilere karşı hangi konumdadır, kendi ana teorisi nedir izah etmez. Zira eğer diğer teoriler doğru ise neden "sürpriz"e sebep olmalıdır veya muhalefet edinilmelidir?

Henle'nin tasavvuruna göre metafor bir "ikonik element" içerir ve ikonik işaret kavramının analiz edilmesi ile de metaforik bir atfa sebep olur. Onun Keat (John Keat 1795- 1821; İngiliz şair) menşeili misalinde (To Hope'tan) "hateful thoughts enwrap my soul in gloom" (Nefret dolu düşünceler sarıor ruhumu kasvetle) iki ilgi vardır. Evvela "enwrap" (sarmak) kelimesi belli bir hareketi işaret eder. Mesela bir pelerini, şalı (vücuduna) sarmak. Buna mukabil kelime bir de "kasvet"ten ikonik işaret edişe sahiptir (Henle 1958, 177-9; 1969, 85-7). Henle'ye göre metaforda bazı kavramlar "ikon"u sembolize eder; diğerleri de "ikonize" edilecek olanı (Henle 1958, 181; 1969, 89; Beardsley 1962/1996, 125).

Buna istinaden sorar Beardsley: Pelerin yahut şal buraya nasıl gelir? İkonik signifikasyon teorisi'ne göre herhangi bir yabancı nesne (Ransom'un "page"i gibi), import teorisi'nde olduğu gibi aynı zorlukları içine alır. Hatta Henle nesne-mukayese teorisi için "uygunluk"u temel edinir ki bu Beardsley'e göre en azından saptırıcıdır. Burada kasıt, yani Henle'nin kastı "nefret dolu düşünceler"in "kasvetle dolaşmak" ile birlikte uygunluk ortaya koyduğudur. Zira her bir keskinlik ve keskin kenar

\footnotetext{
${ }^{12}$ Henle 1958, 173-195; 1969, 80-105. Görüşlerin devamı, daha doğrusu geliştirilmiş ve modifiye edilmiş hâli: The Problem of Meaning, Proceedings and Addresses of the American Philosophical Association 1953-54, Vol. 28 (Yellow Springs 1954).

Signifikation'u en kaba hatları ile izah gerekirse: Dâl kendi dışında bir şeyden haber veren, onun varlığına işaret eden, onu gösteren bir unsurdur. Belâgat bu unsurun söz olanı ile ilgilenir. Medlul bu sözün gösterdiği şey, yani gösterilen 'dir. Bu ikisi arasındaki ilişkiye de delâlet denir. (signifikant + signifikat $=$ signifikation $)$

Dâl: signifikant (gösteren)

Medlûl: signifikat (gösterilen)

Delâlet: signifikation
} 
"kasvet"e uygunluğu tahrip edecektir (Henle 1958, 180; 1969, 88). Yani "Rüya gibi bir resim" (s.32) teşbihinde rüya nasıl olmuş da buraya gelmiştir sorusunu sormak ile taşınan unsurun yabancılığını kasıtla uygunluğunu da sorgulamış oluruz.

Beardsley burada eleştirinin oldukça garip bir ilkesini genellenebilir görür. Onun kanaatine göre, daha doğrusu soru biçiminde ifade edilebileceği üzere acaba "sarmak" kasvet kelimesi için en uygun ikonik işaret midir? Mesela "dolanmış" denebilir mi? Bu cevaplanabilir bir soru değildir; zaten diğer ifade (cümle halihazırda böyle kurgulandığı için) yerleştirilebilir değildir. Eğer şair "ruhumu sarıyor" yerine "ruhuma dolanıyor" demiş olsa idi başka bir şey söylenmiş, duygu başka türlü ifade edilmiş olacaktı. Burada iyi şiir, iyi ifade, üslup vb. tartışmalar devreye girecek ve aslında "metaforik" tavrın ötesine geçecektir kasit. Bu durum okuru "yorum" sürecinde kısmen pasif kılarken yazarı kullandığı her bir sözcük için daha sorumlu tutar.

"Hiç bozulmamış; geç kalmasaydım böyle olmazdı belki. Üzüldü. Fakat hiç değişmemiş; son gördüğüm gibi, gözleri bile açık. Yalnız, gözlerin bu canlılığında bir başkalık var: her şeyi bildiği halde duygulanamayan bir ifade. Görünüşüme bakma, içim öldü artık diye korkuturdu beni. İnanmazdım. Öyle şeyler bulup söylerdi ki öldügü halde. Belki beni izliyor gene. Yerini değiştirdi. Benimle ilgili değilsin diyerek üzerdim onu. Hayır, bakmıyor bana. Belki de düşünüyor. Birden konuşmağa başlardı. Bütün bunları ne zaman düşünüyorsun? diye sorardım ona. Ne zaman düşündüğünü bir türlü göremiyorum. Hayır, gerçekten ölmedi; çünkü ben yaşayamazdım ölseydi.” (s.30).

Mesela yukarıdaki paragraf için "acaba o ölseydi ben yaşayamazdım diyen kadın başka birisi ile evlenmiş, gayet mesut, tavan arasına çıkana kadar eski sevgilisi aklına gelmemiş biri nasıl olur?" sorusunu soramayız. Veya "Seni çok mu yalnız bıraktılar sevgilim?" (s.33) dediğinde onu duyan kocası, kadının yere düştüğü ve masanın devrildiği hengâmeyi işitmez: "Dizleri titredi, dişleri birbirine çarpt1, ayağının altından kayıp gitti döşeme; kayarken de ayağına çarpan resim masası devrildi" (s.29)

$\mathrm{Bu}$ tavrın sebebi sorsak da cevap alamayacak olmak değildir; sebep yazarın $i k o n i k$ ifadeler seçiminde tam tasarruf sahibi olduğunun tasdik edilmesidir. Mesela "ne zaman düşündüğünü bir türlü göremiyorum" ifadesini yorumlarken "kadın" ve "tavan arasının" dışına çıkmadan ikonik bir süreç belirlemek zorunluluğu sebebi ile pasif kalan okur şu hâlde metin bitene kadar bir kanaat belirtmek riskine girmemelidir. Bu tavrın şüphesiz "bağlam üstüne hakimiyet" gibi büyük bir faydası olsa da uzun metinlerde kontrolün kaybedilmesi, metaforik inceliklerin kaçırılması ve daha da önemlisi sentaktik- semantik ve pragmatik geçişlerin yakalanamaması gibi riskleri de vardır.

Henle Aristoteles tarafından verilen "orantılı analoji”nin ters çevrilebilirliğine atıfta bulunur. Malum "kâse" ve "kalkan" misalini verir. Kalkan, Ares'in kasesidir; kâse de Dionysos'un kalkanı (Poetik 1457b 20; Rhetorik 1407 a14). Henle'ye göre bu tür bir ters çevirme (inversion) metaforun ikonik karakterine dayanır (Beardsley 1962/1983, 126; Henle, op.cit., 190 [99]'dan). Buradan madem A, B ile mukayese ediliyor; o halde neden B de A ile mukayese edilmesin sonucunu çıkarır Beardsley. Elbette buradan teori ile ilgili ağır bir itirazın hasıl olması mümkündür. Beardsley, 
Henle'nin bu konudaki izahını yeterli bulmaz. "Bu adam bir aslandır" ve "bu aslan bir adamdır" misalleri (Beardsley 1962/1983, 126 vd) ${ }^{13}$ metaforik niteleyicinin her bir özne için ne kadar farklı olduğunu gösterir. "Söz+lü muhalefet" teorisine göre tüm A'lar metaforik olarak B olmadığı için tüm B'ler metaforik olarak A değildir. Dolayısı ile metafor ve Aristoteles tarafindan tanımlanan "orantılı analoji" veya "oran benzerliği" arasında fark vardır (Beardsley 1962/1983, 127). İkonik signifikation teorisi açıkça yanlış olduğu sürece; yani böyle kabul edildiği sürece "kelime muhalefeti teorisi" haklı olacaktır. Eğer aslanları insan, insanları da aslan olarak nitelersek; her iki durumda da taraflara aynı özellikleri vermiş oluruz. Sorun resim rüya olduğu kadar rüyanın resim olmasının kesinliğidir. Bu durum artık Ali ve Akhilleus üstü bir durum haline gelir. Yukarıdaki misallerin yan yana konması ile ortaya çıkan fark zaten bu tür bir ters çevirmenin ne kadar mantıksız olduğunu gösterir. Weinrich de aynı misalleri zikrederek problem üstünde durur (1963/199, 338; fakat mukayesenin metaforun temeli olduğu da aşikardır bkz. Weinrich 1976, $308 ; 1980,1179-86)$.

$\mathrm{Bu}$ ters çevirme'nin “duygu değeri”ni ciddi şekilde etkilediği ve hatta metaforik yapıyı rencide ettiği tahmin edilebilir bir gerçektir. Orantılar arası denge kastı ile verilse bile bu yargı tehlikelidir; yanlışa müsaittir. Dolayısı ile "rüyanın resme teşbihi" bu bakımdan ya mantıksızdır ya da çok orijinal bir bağlam içinde ancak anlamlı bir hal alır.

Beardsley'in bir diğer itirazı da ikonik delâlet (signifikasyon) teorisine yöneliktir. Aynı kavram metafor için oxymoron'da (oksimoron) ${ }^{14}$ olduğu gibi analiz edilirse buradan metafor teorisi için olumlu bir netice (dahi) çıkabilir. Bu, teoriyi daha verimli ve ekonomik yapar; ayrıca bu iki ifade formu arasında büyük bir yakınlık olduğunu da gösterir. İkonik signifikasyon teorisi bir dezavantaja sahiptir; zira oxymoron'larda kullanılabilir değildir. "Sessiz çı̆̆lık" misalinde sessiz insan ikonik işarete yönelik olarak bir şey yapmıştır; yani gerçekten de sessiz değildir. Sessizlik burada "ses" için bir işarettir. Bu hiç de ikna edici bir karşılık, özet tanımlama olmaz. Birçok defa oxymoron'lar prototipiktir; yani "söz+lü muhalefet"'in en belirgin ve yoğun şeklidir.

Üçüncü kısımda izahat daha da netleşir. Eğer bir kelimenin anlamından metafor olarak işaret edilen nesneyi kendimiz çevirebilirsek, o vakit metaforun metaforluluğu bir "anlaşmazlık türü" içinde aranmıştır denilebilir. Bu hakiki anlamda katiyen olmaz. Bu anlaşmazlık olarak nitelenen sahada çözüm aramayı Beardsley “çıkmaz sokak" olarak niteler (Beardsley 1962/1983, 127-8). Bu, ifadenin anlamı ile ilgili yaklaşımın, yani bizim anladığımız; ifadeden çıkarılan anlam ile yazarın yahut hatibin kafasındakinin mukayesesi demektir.

"Şimdi onu nasıl inandırabilirim bütün bu süreyi onunla birlikte yaşadığıma?

\footnotetext{
${ }^{13}$ Kubczak benzer bir misal verir: "Menschen sind Schilfrohre (kamıs/saz), bedeutet etwas anderes als Schilfrohre sind Menschen. Im ersten Fall soll etwas über Menschen ausgesagt werden, im zweiten über die Schilfrohre.” Bkz. Kubczak 1986, 92; Kittay 1987, 186-192; Searle 1975/ 1982, 115 vd. Yani "insanlar kamışlardır" demek ile sazlıktaki kamışlar (müşebbehün bih) ve insanlar (müşebbeh) arasında ilgi kurulmaktadır. Bunu "kamışlar insandır" şeklinde çevirirsek anlam bambaşka bir çehreye bürünür. İlkinde insanlar hakkında bir şey söyleriz, diğerinde ise kamışlar hakkında.

${ }^{14}$ Oksimoron: Zit anlamlı sözcükleri bir arada kullanarak anlamı kuvvetlendirme sanatıdır. Mesela: avazı çıktığı kadar susmak, gerçek yalanlar, bakar kör, özgür esir, yaşayan ölü, canlı ceset, cesur korkak, siyah aydınlık, güzel çirkinlik, sessiz çığlık vb.
} 
Onu unutmuş gibi yaşarken onu düşündüğüme? Anlamaz, görünüşe kapılır, anlamaz. Başkasına rastladığım için, bu yeni ilişkinin her şeyi unutturduğunu düşünür. Oysa her şeyi hatırlıyorum; tavan arasına çıktığ1 gün bu elbiseyi giydiğini bile. El fenerini ölünün üzerinde dolaştırdı: Örümcek ağlarının gerisinde sisli bir görünüşü var. Yalnız, ağların arasından elimi, onun kalbine götürdüğüm yer biraz karanlık. Rüya gibi bir resim" (s.32).

Hikâyenin tamamında konuşan kadın ve anlatan yazar üslûbu iç içe geçmiştir. $\mathrm{Bu}$ paragraftaki gibi geçişler çoğu zaman aniden yapılır. Bu da alenen pragmatik sürece müdahale anlamına gelir. Yani biz (okurlar) karakter ile baş başa kalıp semantik sürecin ötesini tasavvur etmeye çalışırken yazar eylemleri tasvir etmekle kalmaz "örümcek ağlarının gerisinde sisli bir görünüş" gibi detaylar ile "perlokasyon-ik" ${ }^{15}$ katmana geçmeye çalışır. Bu müdahale "diyalog- 3. Şahıs" tavrı içinde sorunsuz işlerken burada ciddi anlamda bir sıkışmaya sebep olur. Daha basit bir izah ile:

"Gülümsediğimi gösteren bir ayna olsaydı; biraz da 1şık. 'Bir yerini kırarsın

\footnotetext{
${ }^{15}$ Lokasyonel eylem [eng. Lokutionary act, dt. Lokutionärer Akt]: Dilsel eylemin ses, kelime, cümle gibi ögelerden oluşan kısmıdır. Yani "Eyvah! Böcekler beynini yemişlerdi, en yumuşak tarafını" (s.33) cümlesinin "lokasyonel eylem"ini incelemek iktiza ederse yedi kelimedir, sesleri şudur, gramatiği, semantiği böyledir gibi bilgiler verilir. Yani soyut bir cümledir, öznesi budur, eylemi şu çekimdedir gibi bilgileri de kapsar. Aynı şekilde bu cümleler için yapılacak dilbilimsel tetkikler ve anlam sınırına kadarki mütalaalar bu kapsama girer.

İllokasyonel eylem [eng. Illocutionary act, dt. İl-lokutionärer Akt]: İsminden de anlaşılacağı üzere lokasyonel eylemin zittı gibidir. Dil eyleminin hususi amacını, yani dil eyleminin kurulmasına sebep olan konuşmacı maksadını işaret eder. Bu cümle bir "tasavvur" da olabilir; bir istek, bir yakınma, bir iç döküş, bir lanetleme de olabilir. Ya da dünyanın sonu ile ilgili bir kehanet. Alan çok geniştir. İngilizce yapay kelime olan "illocationary act" kabaca "konuşmayı kaplamış eylem" biçiminde çevrilebilir. Austin'in tabiri ile "bir sözlü ifade vasıtası tayini ile bir eylemin tam çizimi"dir.

Perlokasyonel eylem [eng. Perlocutionary act, dt. Per-lokutionärer Akt]: Söz-eylemin etki alanı ile ilgilidir. Austin'in tabiri ile "doing something by saying something". Diğerlerinden farklı bir mecrası (istikameti) vardır. İllokasyonelden farklı olarak dilsel davranışın kendisi ile değil sonucu ile ilgilenir. Yani ifadenin sonucudur mühim olan. Mesela kadına daha sonra ne olmuştur, kocası ile hayatına hiçbir şey olmadan devam mı etmiştir? Kocasına eski sevgilisini unutamadığını anlatıış olsa, kocası buna ne tepki verir? Bir kez daha çıkacak mıdır tavan arasına? İkna, geri çekilme, hayal kırıklığı, endişe, huzursuzluk gibi etki esaslı eylemler bu safhada ele alınır. Austin'e göre perlokasyonel eylem ile perlokasyonel efekt arasında ayrım yapılmalıdır. Perlokasyonel efekt, perlokasyonel eylem kaynaklı olarak ortaya çıkan tesirdir. Mesela kocası, karısının tavan arasında kitap aradığını düșünsün. Fakat asıl tesir kadının hatıraları ile, bilhassa eski sevgilisinin anısı ile yüzleşmek şeklinde olsun. Böylece amaçlanan perlokasyonel efekt başarısız olur. Perlokasyonel eylemin yürütülmesi ancak konuşan kişi tarafindan tasarlanan maksadın eylem ile örtüşmesi durumunda hasıl olur. Perlokasyonel eylem ile illokasyonel eylem arasında bir nedensellik ilişkisi vardır. Bu rabıta konuşma eyleminin bir neticesidir. Buna mukabil illokasyonel ve lokasyonel eylem arasında "içinde olma" rabıtası vardır. Buna göre netice bir dilsel davranıştır ve zamansal açıdan çakışır.

Austin 1972: lokutionärer Akt, ss.110-116, 119-125, 131, 142; illokutionärer Akt, ss. 116-125, 127 136; perlokutionärer Akt, ss.118-125, 127-136. Bkz. Cohen 1973, ss. 492-503. Elbette daha önemli olan metaforun il-lokutionär gücü yahut bu bakımdan garanti altına alınabilirliğidir. Bkz. Cohen 1998, s. 32; Martinich 1984, ss. 35-56; Martinich 1985/1996, s.428. John Langshaw Austin'le (1911- 1960) birlikte "dil-eylem" yahut "söz-eylem" (speech acts) kuramını geliştiren kişi Searle'dür (2005a: 91123; 2005b: 123-305).

Bu konu hakkında ayrıca yakın bir zamanda yayınlanacak olan şu makalemize bakılabilir:

"John Langshaw Austin ve Ted Cohen'in Dil-Eylem (Sprechakt) Teorileri Çerçevesinde Hüseyin Rahmi Gürpınar'ın 'Ecir ve Sabır' Hikâyesine Atf-1 Nazar”
} 
karanlıkta.' Delikten yukarı doğru bir el feneri uzandı" (s.27)

İlk cümle kahraman anlatıcı, yahut onun "iç ses"i. İkinci cümle diyalog; yani illokasyonal sürecin tamamlayıcısı. Sonuncu cümle de Oğuz Atay'ın müdahalesi vardır. Hikâyenin tamamında "iç ses, diyalog ve anlatıcı" birbirine girmiş vaziyettedir. Beardsley'in bu aşamadaki kastı yazarın teamülü ile (burada Oğuz Atay) bizim algımızın mukayesesi esnasında rest çekecek tarafın yazar olmasıdır. Zira yazar metin içinde bir çekişme, bölünme, çözülme ve birleşme yaşarken yani kendini nispeten mücerret kilarken biz (okurlar) verilenler ile iktifa etmek zorunda kalırız. Dolayısı ile "yazarın iç dünyası hakkında metinlerden hareketle ahkam kesmeye kalkmak" ciddi anlamda dramatik neticeler verebilir.

\section{Kinâye Kastı}

A'nın metaforik olarak B diye isimlendirilmesi, kasit olmadan (buna gerek olmadan) A, B'dir demeye benzer. Bu durumda kaçınılmaz şekilde metafor ironi'nin bir formu olur. Bu aşamada Anthony Nemetz'i misal verir Beardsley. Nemetz, makalesinde (1958, 417-442) metaforu oluşturan iki temel öge üstüne kurar argümantasyonunu: (1) ne söylendi. (2) ne kastedildi. (s.419) O halde soru şu: $\mathrm{Bu}$ ikisi arasında nasıl bir ilişki vardır? Beardsley'e göre bu formül yanlış bir istikameti işaret eder. Metafor; deyim, tabir gibi bir ifadedir. Biz bir kelimeyi ya metaforik anlamda (mecaz katmanında) ya da hakiki anlamda zikrederiz. Her iki durumda da ne söyler isek o kabul edilir; yani kastımız bellidir. Resmi rüyaya benzetmekte maksat rüya üstüne düşündürmek değil "resme" ait bir özelliği öne çıkarmaktır.

Kinayeli kullanımlarda da ne kastediliyorsa zaten maksattır; muhalefet sınırı ona göre belirlenir. Mesele "söylemek" ifadesini her iki durum için kullanmaktır. Yani Beardsley nazarında kısaca ya metafor vardır, ya da yoktur; var ve yok olma durumu bilinmiyormuş gibi "söylenen" ve "kastedilen" arasında fark aramak gerçekten de mantıksızdır. ${ }^{16}$ "Ruhum daralıyor" derken kişinin bununla gerçek anlamı kastetmesi mümkün müdür? Ruh gerçekten daralır mı? Bir nesne midir ki ruh? Yorum süreci ifade için bir "idrak süreci"nin başlaması demektir; dolayısı ile kasıt bir şekilde tespit edilir ve anlam ona göre çözümlenir. Eğer söylenen ve kasıt arasında bir muallakta kalış söz konusu ise o vakit semantik bir hata mevzubahistir. Aslında anlamın hangi yöne gittiğinin belirlenmesi idrak için ön şart konumundadır. Edebi metni oluşturmaktaki yahut konuşmaktaki kasit tüm problemlerin odağ 1 konumundadır. Bir şiirde ifadenin metaforik kullanımı bizim şairle bir nevi aynı dile adapte olmamız anlamına gelir. Velev ki metaforik kullanım "hakiki" algılansın o vakit anlam daha ilk mısralarda bükülür yahut kırllır. Beardsyley'in bilhassa muhataba (şair'e bilhassa) topu atıyor gibi görünmesi aslında belli bir idrak düzeyi üstündeki okur/dinleyici talebenin meşrulaştırılmış ifadesidir. Yani şiirdeki mecazı bile ayıramayan biri ile metafor konuşmanın hiçbir âlemi yoktur.

Benzer bir durum için bu sefer Isabel Hungerland'1 değerlendirir Beardsley. Hungerland'ın Poetik Discourse (1958, 108-110) adlı kitabında metafor için mükemmel bir analiz yapıldığını düşünür. Ona göre metaforun alışılmış dilden bir sapma yahut alışılmış dilin ihlali olduğu ispatlanabilir olmalıdır. Veya "ihlal" (yahut

\footnotetext{
${ }^{16}$ Bir şey söylemek ve başka bir şey kastetmek arasındaki çelişkide temelin birincil ve ikincil anlamlar olduğunu unutulmamalıdır (Searle 1982, 38).
} 
sapma) kasıtlı yapılmış olmalıdır. açıktır”.

Birkaç misal verelim: "Ali’nin kemeri uzundur", "Onun kapısı her daim

İki misal de klasik (ve yanlış) olarak "kinâye" kabul edilir (Duman 2018: LS 5.11; s.448-50). İlkinde mecâz ve hakiki anlam gereğinden fazla bağlantılıdır. Yani "kemeri gerçekten uzun olmak" ile "şişman" olmak aynı kapıya çıkar. Burada lafzın kabalığından dolayı "şişman" lafzına îmâ vardır. Yani şişman olmak kemeri uzun olmayı zorunlu kılar. Diğer misalde kapının açık olması cömertlik için bir gerekliliktir. Ama cömert, misafirperver kişinin cismanî anlamda kapısı sürekli açık kalacak değildir. Bir adım önce olarak Hungerland'ın yargısı gereği buradaki sapma yahut ihlal ispatlanabilir olmadığı için (ki bunun en büyük müsebbibi bağlam eksikliğidir) metaforik kullanımdan söz edilemez (Beardsley 1962/1983, 128).

Burada metaforun bir nevi "dikkatsizlik" içinde değerlendirilmesi sonucu tesadüfi yahut kasıtsız olması durumu şüphesiz istisnai olarak mümkündür. ${ }^{17}$ Şairin hayal dünyasındaki çentiklerin normal zihin tarafindan çözülmeye, düzeltilmeye çalışılması esnasında "idrak kazaları"nın olması metafor tesisi için bir problem olmakla birlikte katiyen sürekli bir engel değildir. Yani Oğuz Atay’ın yarattı̆̆ bir kadın kahramanın tavan arasında eski sevgilisine rastlaması mantıksız, saçma, tuhaf ve anlamsız gelse de "metin" bir kımete sahiptir. Yazarın kastını görememek, alt metinleri okuyamamak ve pragmatik katmana geçememek bir idrak kazası olarak (her zaman geriye dönmek ve metin üstüne düşünmek imkânı bulunan) okuru işaret eder, yazarı değil.

Aksine bir surette metafor yapan bir ifade kendi anlam yapısı içindedir. "Söz+lü muhalefet" teorisinin merkezi görünüşünü Beardsley halihazırda Aesthetics: Problems in the Philosophy of Criticism'de (1958, Kap. III) izah etmiştir; burada bir kez daha üzerinden geçer. Aslında söyledikleri şimdiye kadarki ifadelerin tekrarından başka bir şey değildir. Yaşayan dilin anlam üstünde kurguladığı yapı (anlama verdiği imkân) ile metafor arasında hissedilir bir fark olması gerekir. "Unutulan" hikâyesi metaforik bakımdan zayıf yahut yetersiz görünse de kurgu ve buluş (de Inventione) bu açığı kapatır.

Genel ifadenin tavrı onun işaret fonksiyonunu da oluşturur; Beardsley bu vesile ile özelliklerin iki bölümü arasındaki farkı öne çıkarır. Evvela -en azından verilen bir bağlamın mantığı içinde (yani ne dediği açık seçik bilinerek)- ifadenin somut kullanımları gerekli koşullar olarak belli bir mantık içinde görülür. Yani? Bu özellik tanımlanabilirdir ve işaret edilen, belli özellikleri gösterir. Bağlam içindeki ana anlamdır, denir ise muhtemelen daha net anlaşılır. İkinci özellik+ler ifadenin yan anlamına aittir veya (kelimenin edebî sahadaki anlamı olarak) çağrışımlarına. $\mathrm{Bu}$ özellikler konuşanın, nesnenin ilgili bağlamında bariz bir şekilde atfettikleridir; bu sayede bir kural iddiasinda bulunulmadan ifadeden istifade edilir. Zira nesnenin potansiyel olarak bu özelliğe sahip olabilirliği olmasa idi, o nesneye bu ifadenin kullanılması istenmezdi.

${ }^{17}$ Beardsley bunun için Percy'nin makalesine $(1958,79-99)$ atıfta bulunur. 


\section{Tesadüfilik}

"Söz+lü muhalefet" teorisinin basit formu bir noktaya kadar doğrudur Beardsley için. Yani tanımlanan fenomen; denotativ (ana) anlamdan, konnotativ (yan/ çağrışımsal) anlama kayış gerçekten gözlemlenebilirdir. Fakat Beardsley bu tanımın yeterli olduğu konusunda endişelidir. En azından bazı metaforlarda başka şeyler mühim rol oynuyor olmalıdır. İzahın eskisine nazaran daha sarih olması amacı ile iki ayrım yapar. Bir kelimenin çağrışımsal anlamı (ki bu nesnenin belli bir sınıfında durmaktadır) genel kabulün aksine tesadüfi özelliklerin toplamında konuşlanmıştır. Bu özellik ya nesneye verilmiş'tir ya da nesnede mevcut'tur.

Tesadüfilikten kasıt, mesela "rüyâ" gibi denmek ile çok güzelin anlaşılmasıdır. Rüyanın güzel addedilmesi muhtemel bir özelliğin öne çıkarılmasıdır. Bu nitelik her rüyada yoktur, dolayısı ile bu nitelik atfedilmiştir.

Kadın tavan arasında kitaplarını aramaktadır: "Bir an önce kitaplara ulaşmak istedi, geriye doğru bu sonsuz yolculuk bitsin istedi" (s.29). Kitap aramak (müşebbeh) çağrışımları ve ifade ettikleri ile "sonsuz bir yolculuk"a (müşebbehün bih) teşbih ediliyor. Sonsuz yolculuk da nedir? Böyle bir şey yapılmış mıdır ki? İnsan fiziksel olarak sonsuz değildir ki yolculuğu sonsuz olsun. Dolayısı ile çağrışımdaki bu koşulsuz kabul tesadüfi özelliklerin mevcut olmasından ziyade verilmesi yani atfedilmesi ile alakalıdır.

$\mathrm{Bu}$ tesadüfi özelliklerin miktarını kelimenin saha potansiyelli çağrışımlar'1 olarak adlandırır Beardsley. Bu aslında bizim en sağlam olduğunu düşündüğümüz "Alan Teorisi" ile de ciddi bir dirsek teması anlamına gelir (Duman 2018: LS. 3.12, s.301-11). Bunu kabaca "kelimenin kelime ile idraki" biçiminde özetlemek yeterli olmasa da fikir verecektir.

Dördüncü kısma bir varsayımla başlar Beardsley. Mesela "kararsız" kelimesi ("kararsız ay" için) ilk defa metaforik olarak kullanılmış olsun. Yahut en azından ilk defa cansız bir nesneye tatbik edilsin. Bu kullanım(ın böyle olması) kelimenin daha önceden de cansız varlıklar için tatbikini garanti altına almaz. Aslında Beardsley'in burada kıyısından köşesinden ele aldığ 1 "metaforun kökeni" meselesi yine kendi tabiri ile söylemek gerekirse "çıkmaz sokak"tan başka bir şey değildir. Yani ilk defa kim bir şeyi "sonsuz yolculuk" olarak nitelemiş olabilir ki? Mühim olan metaforun değerlendirilme kriterleridir, neye metafor denip neye denmeyeceğini etimolojik çözümleme ile belirleyemeyiz. Zira metaforu tüketen kalabalıklar ciddi anlamda bu malumatın tatbikinde geri dönüşe kapalıdır. Kelime (burada "kararsız") ilk ortaya çıktığı zamanlarda bu çağrışımsal anlama sahip değildir (Beardsley 1962/1983, 1323). "Kararsız ay" dendiği vakit yine zıttı kelimenin içinde aranmaktadır; yani uygun bir "hakiki- çağrışımsallık" ayrımına girişilmesi bizi bazen çaresiz durumda bırakabilir. Peki bu ifade nasıl izah edilebilir? Genel üslup özellikleri ve sentaktik bağlantılar sebebi ile ortaya atılan iddia tamamıyla sarihtir, anlaşılır. İdraki sorunsuz olduğu için mantıklı yapılması gerekir. Genel olarak "kararsı insanlar için geçerli olan tesadüfîlik" veya kararsız insanların sahip olabileceği özellikler veya ay'da mevcut olan özellikler; bunların hepsi oyuna dahil olur. Bu özellikler (şu an itibarıla) en azından kısmen "kararsız" kelimesinin anlamından olacaktır. Kelimenin geçirdiği değişimi (gerçek ya da ilave edilmiş) özelliğin anlama (sense) dönüşmesi biçiminde niteler Beardsley. Yani evvela içinden çıkılması imkânsız sınırında da olsa ilk eşik zaman'dır; akabinde şair faktörü devreye girer. Mesela 
şairin biri çıkar da "kararsız" kelimesini başka bir kullanım imkânı içinde konuşlandırırsa bu (bir şekilde) benzer özelliklerden huruç etmiş olarak benzer veya çakışan bir anlam meydana getirecektir. Bu yeni anlam kelime ile oldukça yakın bir anlam ilişkisinde olacaktır; zira kelime ziyadesi ile sabit bir çağrışım dairesine sahiptir. Şu hâlde Beardsley’e göre sadece potansiyel çağrışım yenilenmez, bilakis (ve hatta) yeni bir "ana çağrışım" tesis edebilir.

\title{
Evvel Zaman İçinde
}

Bazen metaforun izahı sırasında nesnenin özellikleri niteleyici sayesinde "ana" hale gelebilir. Ancak bu nesneler mukayese amacı ile başvurulabilir nitelikte değildir. Birçok defa tesadüf olunduğu üzere bu, ilgili özelliklerin yeni bir statü kazanması şeklinde tezahür eder.

"Zaman" çıkmaz sokağında devam eder Beardsley. Farzımuhal belli bir zaman diliminde İngilizce'de "gülümseyen gökyüzü", "gülümseyen deniz" ve "gülümseyen bahçe" kullanımları mevcut olsun. Modifikatör (niteleyici = değiştirici = gülümseyen) elbette her bağlamda aynı anlama sahip değildir. Ancak bu misallerden "ortak bir anlam" çıkarmak mümkündür. Varsayalım ki bu ortak anlam "gülümseyen"in çağrışımı olarak sabitlensin. O zaman bir şair ilk defa "gülümseyen güneş" dediğinde ne olur? Mantıksal kontrast gayet açıktır; evvela "gülümseyen"in esas çağrışımına dönülür ve daha sonra da "güneş"e. Bu form söz+lü muhalefet teorisine de uyar (Beardsley 1962/1983, 133-4). Daha fazla ileri gidilemeyeceği için veya zorunlu olunmadı $\mathrm{g} 1$ için daha ileriye gitmeyi gerekli görmez Beardsley. Her ne olursa olsun ifadenin metaforik olduğu sezilir/ seçilir ve bu şekilde idrak süreci başlar. Ancak metafor "metafor" olmak kastı ile idrak edilmez; burada (zaten) oluşturulmuş bir anlam edinilir. Metaforik ifadenin zaten tespit edilmiş ve kullanımda olması ile tespitinin zorlaşması ve kullanımda olmaması arasındaki sınır sanırım Beardsley için de en karanlık kısımlardan biridir.

Unutulan'ın en mühim cümlelerinden biri şöyledir: "Sonra, onu bir süre görmek istemediğim halde, onun orada olduğunu bildiğim halde, tavan arasına bir türlü çıkamadığım halde onu düşündüğümü, onsuz yaşayamayacağımı biliyordu" (s.31). Burada "tavan arası" ile hafizanın, hassaten de "anıların biriktiği yer"in kastedildiği aşikardır. Tavan arasına bir türlü çıkamamak da o anılar ile yüzleşememek, hesaplaşamamak ve hatırlayamamaktır. Bu ayrım ile başlar metaforik süreç. Aynı zaman dilimini paylaşan insanlar için bu benzetme manidardır. "Nasıl ki evde tavan arası eski püskünün, işe yaramazın, ama zamanında sevilenin ve sahip olunanın saklandığı yer ise" girişli izah yapılmadan teşbihin metnin tümüne hâkim bir ilgi olarak kullanıldığı görülecektir.

Başka bir misal:

\author{
Sarı bir altın kavun gibi \\ Duruyor kocaman ay, otlar içinde yamaçta \\ (Rilke; Larenopfer`den)
}

Ayın kavuna benzetilmesi pek alışılmış bir kullanım değildir. Ama ne demek istendiği anlaşılır; yani şairin neden bu metaforik kullanımı seçtiği bağlam içinde 
çözümlenebilirdir. Bu sürecin "nasıl” olması gerektiğine Majakowski'den bir misal vermek mümkündür: "Uranyum kazanmak gibidir şiir yazmak". Mısra'y1 yahut cümleyi bu halde bırakırsak idrak süreci ciddi anlamda tıkanmaya uğrar. Tespit kolaydır "uranyum" ile "şiir" arasında bir teşbih kurulmuştur. Ancak kullanımda olmayan bu benzetmenin bağlamı eksiktir. Devamen şu iki mısra1 eklersek metaforik süreç işlerlik kazanır: "Bir yıl çalışılır/ Ele geçen bir gramdır".

Ele alınan teoride, Paul Henle tarafından da alıntılandığı üzere, oldukça ilginç bir metafor tasavvur edilmiştir. Terbiye ve ahlak üstüne yazdığı kitabında şöyle der Jeremy Taylor (1847'de). "Ifffetli evlilikler onurludur ve Tanrı'nın hoşuna gidendir" (Chaste marriages are honourable and pleasing to God), dulluk "onur ve saflık ile süslenirse sevimli ve zariftir" ([...] amiable and comely when it is adorned with gravity and purity), bakirelik ise "meleklerin hayatı ve ruhun emayesidir" (a life of angels, the enamel of the soul [...]). ${ }^{18}$ Bu misal "enamel" (emaye) kelimesi için en erken misal değildir. Donne 1631'de ifadeyi "her güzel öğretiyi iyi işlerin emayesi ile kaplamak" ve Evelyn de 1670'de "karakterini emaye kaplamak" şeklinde zaten kullanmıştır. Başka bir misalde de, bir vaazında, "[...] her hakikat emayedir ve kilisemizin güzelliğidir" der. Bu kullanım Beardsley için muhtemelen "emaye"nin ana-çağrışım(sal) anlamıdır. Belki de değildir, der Beardsley (Beardsley 1962/1983, 134). Aslında bu kadar tereddüt içinde tespit takibi ciddi anlamda zemini yumuşatmakla beraber mühim bir gerçeğin de vurgulaması anlamına gelir. Biz bir sözcüğün "metafor" olup olmadığını anlayabilmekle iktifa etmeliyiz, yoksa Beardsley gibi (temsilî de olsa) kim ne zaman, nerede kullandı'nın peşine düşersek çerçevenin genişliği içinde kayboluruz. Yaşadığımız zamanda "emaye" ile ilgili daha net tasavvurlarımızın olması doğaldır; sert, çizilmeye ve darbeye dayanıklı, birçok işlemden geçtikten sonra elde edilen bir kaplamadır emaye. Cam hamuruna silisyum, soda, boraks, kurşun ve bazı metal oksitlerin katılması ile elde edilir. $\mathrm{Bu}$ kelimenin baz özellikleri muhtemelen kelimenin bilinen/ tanınan çağrışımları değildir. Bakirelik için "ruhun emayesi" demek (Henle'nin de ifade ettiği gibi) ruh için bir "koruma" hükmünde olsa gerektir. Ayrıca "emayenin" (cama benzer bir yüzey oluşturmak sureti ile) estetik bakımdan da kaplandığı elemente ciddi katkıları olur. O halde buradaki metafor gizli çağrışımları gün 1şığına çıkarmış değildir; bilakis daha önce düşünülmeyen (/akla gelmeyen) bazı özellikleri oyuna katar (Beardsley 1962/1983, 135).

Kelimenin anlamında meydana gelen bu metamorfozu, bilhassa geçişler açık bir şekilde sınırlandırılmamış ise en azından üç basamağa ayırmak gerektiğini düşünür Beardsley:

(1) İlk basamakta kelime ve özellikleri bulunur. Ki bunlar kesinlikle her kelimenin anlam-kasıt'ının parçası değildir. Kelimenin bazı özellikleri bu kapsama girer; yani bunlar çağrışım kapsamında kabul edilebilir. Yani hikâyeden bağımsız olarak "tavan arası" hangi özelliklere sahiptir ve değildir ile metin dahilinde "tavan arası" hangi özelliklere sahiptir ve değildir, birbiri ile kıyaslanır. Burada kastedilen aslında (gerçekleşen veya tahmini) tipik özeliklerdir. “Ağaç”a ilişkin kullanımlarda bunun mesela kök-dal ilişkisi içinde, yahut yetişmek- ilgi ekseninde veya da farklı1ıklar üstüne olması gibi. Bu özellikler normal şartlarda ve karakteristik olarak nesnede bulunanlardır. Buna misal olarak Beardsley emaye'nin "beyaz" olmasını bir

${ }^{18}$ Taylor 1847, 56. Henle bu misali sempozyumdaki sunumunda kullanır. Beardsley 1962/1983, 134. 
çağrışım özelliği sayar. Yani zaten nesnede olan üstüne kurulması bir çağrışımın bu kapsamdadır. Bu beyazlık emaye ile kaplı nesneyi dış tesirlerden korur veya en iyi emaya beyaz veya en beyaz şey "emaye kaplı" olabilir. Eğer bir kelime belli bir bağlamda metaforik olarak kullanıldı ise bu daha önce sadece özellik olan şey en azından geçici olarak anlama dönüşür. Bu metafora duyulan genel aşinalık veya benzeri bir durum özelliği anlamın sağlam bir bileşeni yapabilir.

(2) Bu bağlantı üstünden düşünülürse ikinci basamakta kelimenin kullanımı için gerekli bir koşul yoktur. Tavan arasını unutulanlar, hatırlanmayanlar, eskiler için kullanılırsa "tavan arası"nın bağlam dışındaki başka özellikleri öne sürülüp bir değerlendirme yapılamaz. Eğer biz ağacı "yükseklik" çağrışımı içinde kullanıyorsak kısa veya bodur ağaçlardan bahsederek itiraz edilmesi ihtimali yoktur. Eğer birisi kalkıp da ağaç "tam anlamıyla" ağaç olmalıdır der ise muhtemelen kişinin etkileyici yüksekliğin başka bir türünden bahsettiği hesabı katılmalıdır (Beardsley 1962/1983, 135).

(3) Eğer bir çağrışım belli bir bağlam için standart hâle gelmişse, kelimenin bu bağlam içindeki kullanımının gerekli şartları yeni bir statü elde eder. (Yani?) Kelime yeni bir standart anlam kazanabilir. Bu basamak için "ölü" metafor olan "kuyruk" misalini verir Beardsley. Bunun arka farlarla ilgili kullanılması ve daha fazla hayvan kuyruğu ile alakalı olmaması, gibi. Tabi bu "arka far" bize biraz yabancıdır; bunu yerine "kuyruklu yalan" yahut "kuyruk gibi peşinde dolaşmak" ifadelerini kullanabiliriz. Her hâlükârda bunların hayvan kuyruğu ile alakası sadece bir "özellik" transferinden ibarettir. Yoksa yalanın hayvan ile, yahut hayvanın bir uzvu ile doğrudan alakası olmaz, yani bu anlam "hayvan"dan bağımsızdır. Her çağrışım bu üçüncü seviyeye ulaşamaz Beardsley’e göre (1962/1983, 136).

Bir misal ile tasnifi tadil etmek mümkündür:

"Neden koşuyorduk, acelemiz neydi? Tavan arasına çıktığı güne kadar, bir şeyin arkasından hep başka bir şey yaptık; hiç durmadık, hiç tekrarlamadık. Sonra, köşemde kaldım günlerce; ne yedim, ne düşündüm. Sigara içtim durmadan. Evi, yaşanmaz bir duruma getirdim sonunda. Bir savaş sonu kargaşalığı sardı her yanı" (s.32).

Ayrılık sonrası vaziyet "savaş sonu kargaşası"na teşbih edilmektedir. Birinci aşamada "savaş sonu kargaşası"nın hususi özelliklerin belirlediği genel çağrışım ağı düşünülür. Yani bu tür bir tablo nelere sahiptir? Yaralılar, ölen insanlar, yıkılan evler; daha da detaylı düşünülürse yetim kalan çocuklar, dağılan aileler, hayvana dönüşen askerler, bir sürü silah, litrelerce kan, göz yaşı vb. İkinci aşamada bu özelliklerden işimize yarayanı alıp sınırlandırırız. Bize lazım olan sadece savaşın "karmaşa" özelliği. Son olarak da savaşın bu özelliği alındıktan sonra diğer özelliklerin dışlanması gelir. Yani yukarıdaki "savaş sonrası" ifadesi ölü, yaralı, yetim çocuk vs. içermez.

Bu gelişimin bir parçasını takip etmek üzere "sıcak" ve "sert" gibi misallerle devam eder Beardsley. Ki bu ifadeler "duyular ile algılanabilirlik" sahası kaynaklıdır ve insanî karakter(ler) için kullanılabilir. ${ }^{19}$ Beardsley'i varsayıyorum ön koşulu ile devam ettiği cümlede "sıcak" kelimesi (şu an itibarıyla özellikleri devamen

${ }^{19}$ Beardsley, karakter metaforlarının oldukça ilginç bulduğu analizi için Solomon E. Asch'e atıfta bulunur. Asch 1955 ve Asch 1958. Ayrica bkz: Brown 1958, 145-154. 
çağrışıma sahip olmasa bile) bir kişi için (şeylerin sıcaklığına bağlı olan tesadüfî özellikler ile) kelimenin yeni anlamı üstünde kısmen işlev değiştirmelidir. Mesela nasıldır sıcak insan? Bunu herkes tasavvur edebilir; cana yakındır, çevresi ile iyi geçinir, çekicidir vs. Bu (ve benzeri) özellikler "sıcak"1n potansiyel çağrışım sahasına aittir; yani sıcak şeyler (hassaten objeler) üstünde düşünülmeden önce kişilik özelliği olarak kavranır. İşin garip tarafı ise sağlamlık sebebi ile hakiki anlamın ön planda bulunması gerekliliğine rağmen malum kişilik özellikleri için akla gelen esas ifadelerdendir "sıcak". Daha da netleştirmek gerekirse; bir kişinin samimiyetle ilgili meziyetlerini uzun uzun siralamak yerine "sicak kanlı" demek yeterli olur. Fakat, bu özellikler "sıcak"ın ana çağrışımına ait olmadan evvel, mutabık olunan metaforik kurgunun sağlanıp sağlanmadığını tespit için bu kelime ile ne kastedildiği yahut edilebileceği bilinmelidir. Nihayetinde "sıcak insan" ifadesi metaforik karakterini kaybedebilir; öyle ki yeni çağrışımı "sıcak" için yeni işaretler içerebilir. Bununla sıcak'ın hakiki anlamda kullanılması kastedilmiyor; eğer "sıcak kanlı" dediğimizde metaforik sürecin gerekliliği olan idrak devri sağlanmıyorsa (ki sağlanmıyor) o vakit metafor ölüdür. Yani "sıcak kanlı" demek hiçbir edebî; metaforik değere sahip değildir.

\section{Philadelphia ve Limon}

Eğer revize edilen "söz+lü muhalefet" teorisi doğru ise izah sahası azami derecede geniş olacaktır Beardsley’e göre. Basit bir teoriden daha fazla "bizim repertuarımızdaki metaforlar hangi ölçüde hayret vericidir"i ne kadar sınırın ötesine geçirebiliriz'i izah eder. Peki, bu ne anlama gelir? Mevzuyu Wallaca Stevens'in (1879-1955) "The Motive for Metaphor" isimli şiiri $(1955,286)$ ile izah eder Beardsley. Metafor bizi değişiklikler ve tecrübelerin naif boyutunu tanımlamaya, düzeltmeye ve korumaya muktedir kılar. Anlam dar anlamda genişletilmediği sürece metafor dilsel ifade vasıtalarımızı artırır (Beardsley 1962/1983, 136-7). Şiirsel alana geçildiğinde şüphesiz bizim de "masif" metafor kabul ettiğimiz metaforun özellikleri zikredilir (Duman 2018: LT 1.3, s.623-4). Bu tür metaforlar "yeni+den yaratım", "anlam değişimi” ve hatta "radikal anlam farklılıkları ortaya koyma" gibi kısa tanımlarla iç içedir. Kelimenin daha önce söylenmemişliği ve şaşırtıcı tasavvurlara vesile olması kelimenin tesadüfen de olsa yeni bir tertip kazanmasına aracı olur. Eğer kelimenin çağrışımları ve şeylerin özellikleri "öznelerarası" tespit edilebilirliğe sahipse (yani böyle bir garanti var ise) o vakit metaforun objektifliğinden bahsedebiliriz. Bu fikir ayrılıklarının da silinmesi, ortadan kalkması anlamına gelir. Bearsley'in üstünde durduğu ikinci kısım metaforların "anlaşılmazlık" ve "bilmecevari yapıya sahip olmak" ile alakası tam olarak çözümlenmiş değildir. Bu tür bazı ifadelerin belirli bir süre sonra tam anlaşılır hale gelmesi, yani metaforun "aşınması" yine zaman faktörünü bu tür sağlam bir zemin teşkil etmekte büyük bir engel haline getirir. Hikâyedeki "çocuk gibiydi, kendisine bakmasını bilmiyordu" (s.31) buna bariz bir misaldir. Artık birine "çocuk gibisin" dendiğinde bir süre düşünülmesine dahi gerek kalmadan ne kastedildiği anlaşı1ır.

Beşinci ve son kısım daha ziyade "uyumsuzluk" üstünedir. Eğer yeni teorik gelişim sayesinde iki ihtimale karşı mevcut itirazlar savunulur ise "söz+lü muhalefet" teorisi revize edilmiş formunda metafor için mühim ve tatmin edici izahat verebilir (Beardsley 1962/1983, 137). 
İlk itiraz "extensionalistik anlam teorisi" temsilcileri tarafindan (intensionalistik anlam teorisinin aksi olarak) dile getirilir. Söz+lü muhalefet teorisi özelliklerin kategorisi olmadan bir bütün oluşturmaz. Burada özellikler denerek "nitelikler" ve "rabitalar" kastedilir. Zira burada birbiri ile uyumlu olmayan özelliklerden bahsedilmektedir. Extensionalistik anlam teorisi temsilcileri herhangi özelliklerin olabileceğine inanmazlar. "Uyumsuzluk" kavramı metaforun, basit bir şekilde, ifade hatasının özel bir durumu olarak nitelenmesi ile bağlantılıdır. Burada hakikatte metaforik kastın gerçekleşmemesi öne çıkarılır. Fakat belki de şaşırtıcı ve belirgin olmayan bir denk gelme söz konusudur. Yani birine "kabak kafa" dendiğinde yahut kişi "aslan" olarak nitelendiğinde kasıt içeren ifadelerin bilinçsizce kullanılması ne kadar imkân dahilindedir? Bu haldeki (ihtimalsizlik içindeki) kasıtayrımı da (bilhassa günlük hayatın alışkanlıkları ve malumat çerçevesi sebebi ile) bir kelime-içi muhalefet olarak değil de metaforumsu kasıt olarak görülmelidir. Ki Beardsley'in tam anlamıyla keskin sınır koymaktan çekindiği bu tür ifadeler bizim B sınıfı dediğimiz metaforlardır (Duman 2018: LT 1.3, s.623-4).

Metaforda ana anlamdan yan anlama bir kayma olur. Ki bu da metaforik olarak anlaşılması gereken kelimeye yöneliktir. Bu anlaşılabilir bir şeydir; absürt değildir Beardsley'e göre (Beardsley 1962/1983, 129). Metaforun bu ihtimalsizlik teorisi için bazı "aldatıcı" misaller ile analizi sürdürür Beardsley. Şakacı birisi "I was in Philadelphia once, but it was closed." der ise bu hakikat ile çelişir mi? Normalde "kapalı" ifadesi müzeler, marketler gibi kapısı olan; belli çalışma saatleri bulunan ve akabinde kapılarını kilitley(ebil)en yerler için kullanılır. Belki ifadeyi fazlaca zorlamadan (hakiki anlam baz alınarak), tüm şehrin kapalı olma ihtimali de düşünülebilir? $\mathrm{Bu}$ durumda hususi bir metaforik tesir devreye girer; kasıt Philedelphia'nın gece hayatı olsa gerektir. Anlam ne olursa olsun kasit ifadenin bu hali ile yanlış olduğunun tasavvur olunmasıdır. (Koca şehir kapalı mı olur?) Zira ifade absürd ve imkansızdır. ${ }^{20} \mathrm{Bu}$ kelime oyunu, bağlam neticesinde değil de kelimeler ile âşikâr olursa (yani mecâzî anlamı kavrar isek) mevzubahis durum her zaman geçerli değildir, yargısını verebiliriz. Diğer uçta da oksimoron durur. Beardsley "Yazamayan yazarlar yazıyorlar." misalini verir (Beardsley 1962/1983, 138). Bu basit bir şekilde sadece ihtimal-dışı değildir; bilakis birçok metafor, tesis edilen bu itirazdan pay sahibidir. Fakat Philadelphia hakkında yapılan nükte oldukça farklıdır. Sınırın belirlenmesidir bir yerde mühim olan; ne tam olarak mümkün ne değildir belirlenmesi gerekir. Zira bu aynı zamanda niteleyicinin hangi anlam katmanında oyuna dahil olduğunu tespit etmemizi de sağlar.

İkinci itiraz şu şekilde formüle edilebilir: Birbirine kontrast oluşturan özellikler birbirine bağlanmalı ise, genel dil kullanımı içinde genel ifade tespiti mümkün olmaz. Yani bu keskin ve sarih bir itiraza sebep olur. Mesela "birader" (brother) ve "erkek kardeş" (male sibling) (sair çağrışımları göz ardı edilirse) en azından ana anlam bakımından pratikte mükemmel derecede sinonimdir. Buna istinaden, "female brother" (kız birader) der isek bu bir iç çelişki hasıl eder. Ancak bu ifade hemen hemen hiç metaforik değildir. Birçok ilginç kelime, ki

\footnotetext{
${ }^{20}$ Beardsley 1962/1983, 138. Onun için absürtlük ironiden oldukça farklıdır. "[...] if the subject is trivial or familiar, the incongruity may appear absurd, and therefore funny; if the subject is serious, the incongruity may appear ironic." Beardsley 1958, 306.
} 
kalıplaşmışlardır bunlar, metaforik kullanıma örnek teşkil etmezler. Zira anlam uyumsuzluğu bir nevi "tabir" katmanında tespit edilebilirdir.

Akabinde Prof. Michael Scriven'den (1958, 105-107) bir misal ile devam eder Beardsley. Limon kelimesi geleneksel anlamda temel tanımlanabilir bir niteliğe (yani şayet kelime doğru bir biçimde nesne üzerinden kullanılırsa ortaya çıan mevcut olmak zorunda olan özelliğe) sahip değildir. Websters'in tanımından alıntı yapar hoca: "Ağaçta yetişen ekşi bir meyve, portakala benzer." Bu tanım limonsallık için gerekli şartları vermez (Beardsley 1962/1983, 139). Ki bu da itirazın muhtevi olmadığı anlamına gelir; yani kalkıp da muz ağacında yetişir, patatese benzer, kabak ile akrabadır falan denmesi mümkün değildir. Prof. Scriven devam eder ve limonun birçok özelliği var iken, bunlar bir arada iken sadece bir tek özelliği gerekli olarak ayıklanamaz der. Yani "savaş sonu kargaşalı̆̆ı" der isek (s.32) özelliklerin ayıklanması mevzubahis olmaz; hepsi bağlama bir şekilde dahil olur. Zira aşk ile "savaş" arasında bir alaka kurulur ise bu aşkın potansiyel olarak yıkım, cinayet, acı, kan, yok etme, parçalama, evinden barkından etme, sürgün, enkaz, yıkıntı, sarsıntı, öksüz, yetim, sakat, mağdur, nefret, öfke, intikam gibi onlarca ifade ile alakalandırılmasına zemin hazırlar. Bu durum birçok ifade için dilin genel kullanımı içinde geçerlidir. Prof. bu kavramları "küme-kavramlar" (yahut deste-kavramlar) olarak adlandırır; bunlar "kullanım kriterleri”"ne sahiptir, fakat gerekli koşullara sahip değildirler.

Kelimelerin kullanımında alanın kapsama ister istemez dahil oluşu bir kaide olarak sürdürülürse (bu kafa ile devam edilirse) ki bu oldukça mühim bir düşünce temelidir, o vakit söz+lü muhalefet teorisi için bir yeniden-formüle ediş gerekir. Eğer, teori doğru ise, limon kelimesi metaforik olarak kullanılabilir olmazdı. Yani teori öylece reddedilebilir gibi değildir. Hocanın da belirttiği gibi: "Hakiki anlam akışkan bir sınıra sahiptir, ötesinde sadece yanlış kullanımlar ve metafor vardır" (Scriven 1958, 119). Eğer limon için gerekli koşullar yok ise o vakit kelime dilsel bir bağlam içinde görünmez. Ki burada bilhassa belli gerekli koşulların mantıksal olarak dışarıda kalması kastedilir. Birçok kullanım kriterinin dışarıda kalmasına sebep olan "bağlam" da ifadenin varlığını sürdürmesine olanak tanıyabilir. Mesela "ikinci el bir arabayı" limon olarak niteleyebilecek olsa idik?

Beardsley'e göre "limon" ve diğer alışılmış kelimeler gerekli koşulları vermez. Bizatihi Prof. Scriven de kendi hususi görüşünün modifiye edilmiş halini ortaya koymuştur. Yani? Belli organik bir yapı (ağaçtan ve balmumu'ndan yapılmak yerine) limonsallık için gerekli koşullara sahip olabilir idi. Elbette burada fiziksel bir objeden bahsedilir, çünkü "ruhanî limon" ya limon'un hakiki anlamı mantı̆̆ında değildir; ya da hakiki anlamda "ruhanî" değildir.

Buradaki soruların son derece "farazî" ve bilhassa soyutluklarından dolayı cevaplarından kesinlik aramanın güç olduğunun farkındadır Beardsley. Buna mukabil makalenin bitimine doğru bir "tasavvur" oluşturur. Bir gün bir şey bulunmuş olsun. $\mathrm{Bu}$ her bakımdan limon gibi görünmektedir. Sadece çapı iki metredir; ki bu vesile ile nesneyi "dev limon" olarak adlandırma eğilimi içinde olunması ihtimal dahilindedir. Bu şüphe (dev limon, demekten imtina etmek) limon için "küçük"ün bir kriter olarak kullanıldığını gösterir; fakat bu muhtemelen limon'un tanımlanabilir bir özelliği değildir (Beardsley 1962/1983, 140-1). Fakat bir kişi alışılmışın dışındaki büyüklüğü hakkında malumat vermeden limondan 
bahsetse, biz onun "küçük" olduğunu tahmin ederiz. Zira hiçbir savaş iyi değildir ve tavan arası evin yaşanan kısımlarından ayrıdır.

A. Pap'tan $(1958,327)$ bir öneri ile devam eder Beardsley: empirik kavramın açık yapısı (open texture/ offene Struktur) ele alınır ve kriterler az ya da çok gerekli olmalarına göre ayrılır ve "anlam tasnifi" mümkün olur. Metaforik niteleyici bu şekilde belirlenebilir; ki niteleyici belli bir bağlam içinde konuşlanır. Bu sayede ya da bu yüzden gerekli şartların gerçekleşmesi olanaksız olur. Küçük/ ufak olmak limon için kaçınılmaz bir özellik ise bu oldukça merkezî bir özellik olmalıdır. Öyle ki kelimeyi metaforik alana taşımak için, bu çelişkili bağlam yeterli olur. ${ }^{21}$

\section{Netice}

Beardsley makalesini bir teslim oluş ifadesi ile bitirir. En makulü soruyu açık bırakmaktır. Üzerinde uzun uzun durulduğu üzere söz/kelime-muhalefet teorisi hem metaforun bilinen özellikler dizisini izahtan; hem de bağlayıc1/ sık1 dil felsefesi içinde tanınır varsayımlar yapmaktan da uzaktır. Sorun tekrar metaforun tanımına rücu etmeyi gerekli kılar. "Metafor nedir?" sorunun cevabının bu kadar muğlak olmasının sebebi disiplinin daha ziyade felsefe içinde konuşlanmasıdır.

Absürtlüğün çözümü yahut idraki aşamasında ilk durak "bağlam”dır. Bağlam metaforik anlamın çözülmesi için bir basamak değil, bir gerekliliktir. Akabinde absürtlüğün mantıksal idrak sürecinde temel element haline getirilmesi teorinin zayıf taraflarındandır. Mantıksal absürtlük yeni bir kavram olduğu ve metnin tamamını hedef aldığ 1 için kabullenilmesi kolay olmaz. Metafor kendi ile çelişen atıflarda tadil edici özellik bakımından uyumsuzluk göstermesi yine bu mantık sorgulaması ile ilgilidir. Yani müşebbeh ve müşebbehün bih arasındaki ilgi tam bir sorgulamadan geçirilmeden metin temize çıkmaz. Yol gösterici yöntem "nesneye yaklaşım" ve "kelimeye yaklaşım" arasında ayrımdır.

Kelimenin harflerden oluşan hali ile gösterdiği nesnenin sadece işareti olması "kelimeye yaklaşım" ile "nesneye yaklaşım" arasındaki mesafeyi iyi ayarlamayı gerektirir. Bu yüzden teşbih, normal şartlarda tarafeynin yan yana getirilmesinin imkansızlı̆̆ ölçüsünde güç kazanır.

Bir diğer absürtlük kriteri olan "mantıklı zıtlık" hem doğrudan uyumsuzluk belirtilen özellikleri hem de çeşitli kelime varsayımları arasındaki dolaylı uyumsuzlukları kapsadığı için İngilizce'de tüm sıfatlar bir şapkanın içine, tüm isimler de bir diğerinin içine konup rastgele örnekler çekildiğinde ortaya çıkan misaller tamamen mantıksız olmayacaktır. Bu minvalde en güvenli kaide tenorvehikel yani müşebbeh- müşebbehün bih terminolojisinin mukayeseye dayanmasıdır. Bu kaide neticeye ulaştırmada da iyi bir başlangıç temin eder. Fakat mukayesenin "uygun" mu "zorlama" mı olduğunu sormak icap eder. Mukayesenin çatırdamaya başladığı an bu andır. Uzun metinlerde kontrolün kaybedilmesi, metaforik inceliklerin kaçırılması ve daha da önemlisi sentaktik- semantik ve pragmatik geçişlerin iyi analiz edilememesi hep bağlam içinde mukayese düzeninin kurulamamasından kaynaklanır.

21 Beardsley'in atıfları: Waismann 1945, 119-150. Ayrıca bkz: Wright 1951: 6, § 2, und Pap, op. cit., chs. 5,11 . 
Metaforun kökeni kesinlikle bilinemez. Zaten kökeni bilinen metafor anlaşılması teminat altında olandır, dolayısı ile $\mathrm{B}$ yahut $\mathrm{C}$ tipidir, yani metaforumsudur. Ayrıca metaforda tarafların yer değiştirmesi tutarsız neticeler verir. A'nın metaforik olarak B diye isimlendirilmesi, kasit olmadan (buna gerek olmadan) A, B'dir demeye benzer. Bu durumda kaçınılmaz şekilde ikinci ters çevirmenin aleyhine olarak ironiyi ortaya çıkarır.

Bir kelimenin çağrışımsal anlamı (ki bu nesnenin belli bir sınıfında durmaktadır) genel kabulün aksine tesadüfi özelliklerin toplamında konuşlanmıştır. $\mathrm{Bu}$ özellik ya nesneye verilmiş'tir ya da nesnede zaten mevcut'tur. Metaforun izahı sirasında nesnenin özellikleri niteleyici sayesinde "ana" hale gelmesi de bunu destekler.

Philadelphia ve limon misallerinin de gösterdiği üzere klişe tavrı metaforik açılımın önündeki en büyük engellerdir. Fakat sabit bir arka planı olmadan yani klişeye dayanmadan metafor kullanma eğilimi her daim muhalefete tabi olabileceği için en zor vazife yazarlardadır. Buluş ve saçmalık arasında çok ince bir çizgi vardır. Bu yüzden Oğuz Atay absürttür, komik değildir.

\section{Kaynakça}

Aristoteles (1982/ 1994a). Poetik, çev. Manfred Fuhrmann, Griechisch/ Deutsch, Stuttgart: Reclam.

Aristoteles (1999). Rhetorik, çev. Krapinger Gernot, Stuttgart: Reclam.

Asch, Solomon E. (1955). On the Use of Metaphor in the Description of Persons, On Expressive Language, ed. H. Werner, Worcester.

Asch, Solomon E. (1958). The Metaphor: A Psychological Inquiry, Person, Perception, and Interpersonal Behaviour, edd. R. Tagiuri/L. Petrullo, Stanford. İletişim.

Atay, Oğuz (1987). Korkuyu Beklerken (Hikâyeler), 2. Baskı, İstanbul:

Austin, John Langshaw (1962). How To Do Things With Words. Oxford: Oxford University Press; Deutsch (1972). Zur Theorie der Sprechakte, Stuttgart: Reclam)

Beardsley, M. C. (1962). The Metaphorical Twist, in: Philosophy and Phenomenological Research 22, s.293-307; (1983/ 1996) Die metaphorische Verdrehung, in Theorie der Metapher, Haz. Anselm Haverkamp, çev. Ellen Karge, Darmstadt: Wissenschaftliche Buchgesellschaft, s.120-141.

Beardsley, Monroe C. (1958). Aesthetics. Problems in the Philosophy of Criticism. New York: Harcourt Brace und World, s.114-147.

Bormann, Claus von (1993). Unglückliche Begegnungen. Gadamers philosophische Hermeneutik und Lacans psychoanalytische Theorie der Deutung, Abhandlung, im Dilthey-Jahrbuch 8/1992-93, s.11-56.

Brooks, Cleant (1947). The Well Wrought Um, New York 1947 [çev. Paradoxie im Gedicht - Zur Struktur der Lyrik (Frankfurt 1965), s.51].

Brown, Roger (1958). Words and Things, Glencoe/III, s.145-154. 
Cohen, Ted (1973). Illocutions and Perlocutions, in: Foundations of language 9/ 1972-1973, s.492-503.

Cohen, Ted (1975). "Figurative Speech and Figurative Acts". In: The Journal of Philosophy 71 (1975), s.669-684. = Johnson, Mark (ed.) (1981), s.182- 199. Çev. "Figurative Rede und figurative Akte". In: Haverkamp, Anselm (ed.) (1998), s.2948.

de Saussure, Ferdinand ([1916]/ 1995). Cours de linguistique générale, Grande bibliothèque Payot.

de Saussure, Ferdinand (1974). Cours de linguistique générale, Edition critique par R. Harrassowtitz, Wiesbaden: Engler.

de Saussure, Ferdinand (1982). Coins tie Linguist it tie Generale. Hg. v. Charles Bally/Albert Sechehaye. Kritische Ausgabe. ed. Tullio de Mauro. Paris: Payot.

de Saussure, Ferdinand (2001). Grundfragen der allgemeinen Sprachwissenschaft. ed. Charles Bally/Albert Sechehaye. çev. Herman Lommel. 3. Aufl. Berlin/New York: de Gruyter.

Derrida, Jacques (1967/1974). Grammatologie. Frankfurt a. M.: Suhrkamp.

Duman, Mehmet Akif (2015). Sorites Paradox/ Yı̆̆ın (Küme) Paradoksu, Akademik Sosyal Araştırmalar Dergisi, Yıl: 3 , Sayı: 12, Haziran, ss. 413-424.

Duman, Mehmet Akif (2018). Von der Rhetorik zum belâgat, vom mecâz zur Metapher (Die Suche nach einer terminologischen Äquivalenz zum Begriff Der Metapher im Türkischen durch Vergleich von Rhetorik und belâgat), Berlin: Logos Verlag.

Eliot, T.S. (1953). Four Quartes, New York.

Hake, Günter; Grünreich, Dietmar und Meng, Liqiu (2002). Kartographie Visualisierung Raum-zeitlicher Informationen, Berlin/ New York: de Gruyter.

Henle, Paul (ed.) (1958). Metaphor, in: Language, Thought, and Culture, Ann Arbor 1958, s.173-195; Almancası: (1969). Sprache, Denken, Kultur, Frankfurt = Theorie der Metapher, s.80-105. Görüşlerin devamı, daha doğrusu geliştirilmiş ve modifiye edilmiş hâli: The Problem of Meaning, Proceedings and Addresses of the American Philosophical Association 1953-54, Vol. 28 (Yellow Springs 1954); (1996) Die Metapher, in Theorie der Metapher, Haz. Anselm Haverkamp, çev. Friedhelm Herborth (Kap. 5-7'yi,), Darmstadt: Wissenschaftliche Buchgesellschaft, ss.80-105.

Hungerland, Isabel (1958). Poetic Discourse, Berkeley/ Los Angeles.

Kittay, Eva Feder (1987). Metaphor. Its Cognitive Force and Linguistic Structure. Oxford: Clarendon Press.

Kubczak, Hartmut (1978). Die Metapher. Beiträge zur Interpretation und semantischen Struktur der Metapher auf der Basis einer referentiellen Bedeutungsdefinition. Heidelberg: Carl Winter. 
Kubczak, Hartmuth (1986). Metaphern und Metonymien als sprachwissenschaftliche Untersuchungsgegenstände, in: ZfdPh 105, s.83-99.

Lacan, Jacques (1997a). "Metapher und Metonymie (I). Seine Garbe war nicht geizig, noch von Haß erfüllt", In: Lacan, Jacques (1997), s.253-262.

Lyons, J. (1991). Bedeutungstheorien (Theories of Meaning). In: Stechow, Arnim von/ Wunderlich, Dieter (Hrsg.). Semantik/Semantics (HSK Bd. 6). Berlin/New York: Walter de Gruyter, s. 1-24.

Martinich, A. P. (1984). “A Theory of Metaphor". In: Journal of Literary Semantics 13, 35-56. Ayn yaz1: Martinich, A. P. (ed.) (1985/1996). The Philosophy of Language. Oxford: Oxford University Press.

Nemetz, Anthony (1958). Metaphor: The Daedalus of Discourse, Thought 33 (August 1958), s.417-442.

Nietzsche, Friedrich (1999). "Kommentar zu Band 1-13", Samtliche Werke Kristische Studienausgabe in 15 Banden $(K G W)$, Bd. 1, Hg. Giorgi Colli, Mazzino Montinari, München: Deutscher Taschenbuch Verlag de Gruyter, "Wille zur Macht", s. 383-400; "Menscliches, Allzumenschliches", Samtliche Werke Kristische Studienausgabe in 15 Banden, Bd. 2, s.30-31; "Nachgelassene Schriften 18701873", Samtliche Werke Kristische Studienausgabe in 15 Banden, Bd. I, "Über Wahrheit und Lüge im aussermoralischen Sinne", s. 875-890.

Pap, Arthur (1958). Semantics and Necessary Truth, New Haven.

Percy, Walker (1958). Metaphor as Mistake, Swanee Review 66 (Winter 1958), s.79-99.

Putnam, Hilary (1975). "The meaning of meaning". In: Ders. (1975). Mind, Language, and Reality. Philosophical Papers, Vol. 2. Cambridge: University Press, s.215-271.- çev. Die Bedeutung von ,Bedeutung'. Frankfurt a. M.: Vittorio Klostermann 1979. (PDF) (1996). in: The Twin Earth Chronicles: Twenty Years of Reflection on Hilary Putnam's The meaning of 'meaning', Ed.Andrew Pessin, Sanford Goldberg, Armonk u.a./ Sharpe, s.3-52. 658

Ransom, John Crove (1947a). II. The Final Cause, Kenyon Review 9, s. 640-

Ransom, John Crove (1947b). Poetry: I. The Formal Analysis, Kenyon Review 9, s.436-56.

Scriven, Michael (1958). Definitions, Explanations and Theories, Minnesota Studies in the Philosophy of Science, Vol. II: Concepts, Theories and the Mind-Body Problem, ed. Herbert Feigl/Michael Scriven/Grover Maxwell, Minneapolis.

Searle, J. (1975/ 1982). Indirect Speech Acts, in Peter Cole and Jerry L. Morgan (eds.), Syntax and Semantics, Vol. 3: Speech Acts, Academic Press, s.5982; Deutsch (1982). In, Ders. Ausdruck und Bedeutung, Frankfurt a.M., s.51-79.

Searle, John R. (1969). Speech Acts- An Essay in the Philosophy of Language, Cambridge: Cambridge University Press.

Searle, John R. (1979/1982). “Metaphor”. In: Ders. (1979), Cambridge 
University Press, s.76-116, ayn1 yazı: Metaphor and Thought, 2.Aufl. Ed. Andrew Ortony, Cambridge: Cambridge University Press, s.83-112. Deutsch (1982). "Metapher". In: Ders. (1982), Ausdruck und Bedeutung, Untersuchungen zur Sprechakttheorie, Frankfurt a.M., s.98-138.

Searle, John, R. (1987). Intentionalität. Eine Abhandlung zur Philosophie des Geistes, Frankfurt: Suhrkamp.

Searle, John R. (2005a). Bilinç ve Dil, Istanbul: Litera Yayıncılık.

Searle, John R. (2005b). Söz Edimleri, Üb. Levent Aysever, Ankara: Ayraç Yayınları.

Spivak, Gayatri Chakravorty (1976). “Translator's Preface.” of Grammatology, By Jacques Derrida. çev. Gayatri Chakravorty Spivak. Baltimore: Johns Hopkins.

Stevens, Wallace (1955). The Motive for Metaphor", Collected Poems, New York. London.

Taylor, Jeremy (1847). Of Holy Living II 3, in Works, ed. C. P. Eden, Vol. III,

Waismann, Friedrich (1945). Verifiability, Proceedings of the Anstotelian Society, Supplementary Vol. XIX, London, s.119-150.

Weinrich, Harald (1963/1976/1996). „Semantik der Kühnen Metapher“, Zuerst erscheinen in: Deutsche Vierteljahrschrift 37 (1963), s.325-344; Sprache in Texten, Stuttgart: Klett-Cotta, s.295-316; in. Haverkamp, Anselm. Theorie der Metapher, Darmstadt: Wissenschaftliche Buchgesellschaft, s.316-339.

Weinrich, Harald (1976). Sprache in Texten. Stuttgart: Klett.

Weinrich, Harald (1980). "Metapher". In: Historisches Wörterbuch der Philosophie. Bd 5. Darmstadt: Wissenschaftliche Buchgesellschaft, s.1179-1186.

Wimsatt, William K. (1941). The Prose Style of Samuel Johnson, Ney Haven.

Wordsworth, William (1950). Notes Toward an Understanding of Poetry, Kenyon Review 12 (Sommer 1950), s.498-519.

Wright, Georg Henrik von (1951). A Treatise on Induction and Probability, London, ch. 6, § 2, und Pap, op. cit., chs. 5, 11.

Zemach, E. M. (1976). "Putnam's Theory on the Reference of Substance Terms", Journal of Philosophy 73, s. 116-127. 